\title{
TNF-like weak inducer of apoptosis inhibits proinflammatory TNF receptor-1 signaling
}

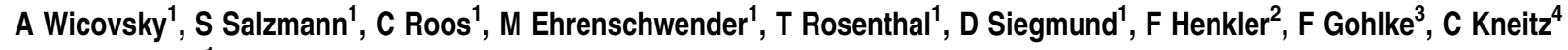 \\ and $\mathrm{H}$ Wajant ${ }^{*, 1}$
}

Soluble TNF-like weak inducer of apoptosis (TWEAK) trimers induce, in a variety of cell lines, translocation of cytosolic tumor necrosis factor (TNF) receptor-associated factor-2 (TRAF2) to a triton X-100-insoluble compartment without changes in the total cellular TRAF2 content. TWEAK-induced TRAF2 translocation is paralleled by a strong increase in nuclear factor kappaB 2 (NF $\kappa$ B2)/p100 processing to p52, indicating that TRAF2 redistribution is sufficient for activation of the alternative NF $\kappa B$ pathway. In accordance with the crucial role of TRAF2 in proinflammatory, anti-apoptotic TNF receptor-1 (TNFR1) signaling, we observed that TWEAK-primed cells have a reduced capacity to activate the classical NF $\kappa$ B pathway or JNK (cJun N-terminal kinase) in response to TNF. Furthermore, TWEAK-primed cells are sensitized for the TNFR1-mediated induction of apoptotic and necrotic cell death. Notably, the expression of the NF $\kappa$ B-regulated, TRAF2-interacting TRAF1 protein can attenuate TWEAK-induced depletion of the triton X-100-soluble TRAF2 fraction and improve TNFR1-induced NF $\kappa$ B signaling in TWEAK-primed cells. Taken together, we demonstrate that soluble TWEAK desensitizes cells for proinflammatory TNFR1 signaling and thus identify TWEAK as a modifier of TNF signaling.

Cell Death and Differentiation (2009) 16, 1445-1459; doi:10.1038/cdd.2009.80; published online 26 June 2009

Tumor necrosis factor (TNF) is a highly pleiotropic, proinflammatory cytokine that is crucially involved in a variety of cellular events, ranging from cell proliferation and differentiation to induction of apoptosis and necrosis. ${ }^{1}$ TNF is primarily expressed as a type II transmembrane protein from which a soluble variant is released by proteolytic processing. The C-terminal part of the molecule, the TNF homology domain (THD), is present in both soluble and transmembrane TNF, and mediates ligand trimerization and receptor binding. ${ }^{2}$ THD is also found in several other proteins and is the structural hallmark of the members of the TNF ligand family. TNF interacts with two receptors, TNF receptor-1 (TNFR1) and TNFR2, both belonging to a complementary family of transmembrane receptors with characteristic cysteine-rich repeats in their extracellular domain: the TNF receptor superfamily. ${ }^{1}$ Soluble TNF binds with high affinity to both TNF receptors, but only properly activates TNFR1, whereas transmembrane TNF activates both TNF receptors efficiently. ${ }^{1}$ With the help of death domain- and TNF receptor-associated factor (TRAF) domain-containing adaptor proteins, the two TNF receptors trigger signaling pathways, resulting, among others, in the activation of nuclear factor kappaB $\left(\mathrm{NF}_{\kappa} \mathrm{B}\right)$ and various MAP kinases, and also in the activation of caspases and apoptosis.

The type II transmembrane protein, TNF-related weak inducer of apoptosis (TWEAK), is also a member of the TNF ligand family that is efficiently processed into a soluble secreted form by proteases of the furin family. ${ }^{3}$ TWEAK weakly induces apoptosis in some tumor cell lines, and also activates proinflammatory signaling pathways, including the classical as well as the alternative $\mathrm{NF}_{\kappa} \mathrm{B}$ pathway, and pathways leading to the activation of ERK, cJun $\mathrm{N}$-terminal kinase (JNK) and Akt. ${ }^{3,4-7}$ Although TWEAK mRNA has been detected in a variety of cell lines and tissues, its expression at the protein level has only been demonstrated at the surface of interferon- $\gamma$-stimulated monocytes. The lack of a correlation between TWEAK mRNA and detectable protein expression might be related to the rapid processing of transmembrane TWEAK by furin and/or by an AU-rich translation inhibitory sequence element in the $3^{\prime}$-untranslated region of TWEAK. ${ }^{8}$ An initial study reported an interaction between TWEAK and DR3 in coimmunoprecipitation experiments with recombinant proteins, and claimed DR3 being a receptor for TWEAK. ${ }^{9}$ However, a couple of subsequent reports failed to confirm this early finding (for example, reference Kaptein et al. ${ }^{10}$ ). Instead, it turned out that Fn14, which was previously identified as a fibroblast growth factor (FGF)-inducible protein, is a bona fide TWEAK receptor. ${ }^{11,12}$ The cytoplasmic domain of Fn14, with 28 amino acids, is the shortest within the TNF receptor family and contains a phylogenetically conserved binding motif mediating an interaction with the adaptor proteins, TRAF1, TRAF2, TRAF3 and TRAF5. ${ }^{4,12,13}$ Particularly, TRAF2 and TRAF5 have been implicated in the TWEAK-induced, Fn14mediated activation of the canonical and non-canonical $\mathrm{NF}_{\kappa} \mathrm{B}$

\footnotetext{
${ }^{1}$ Division of Molecular Internal Medicine, Department of Internal Medicine II, University Hospital Würzburg, Röntgenring 11, Würzburg 97070, Germany; ${ }^{2}$ Bundesinstitut für Risikobewertung, Thielallee 88-92, 14195 Berlin, Germany; ${ }^{3}$ Orthopädische Klinik, König Ludwig Haus, University Hospital Würzburg, Brettreichstrasse 11, Würzburg 97070, Germany and ${ }^{4}$ Klinik für Innere Medizin II, Klinikum Südstadt Rostock, Südring 81, 18059 Rostock, Germany

${ }^{*}$ Corresponding author: H Wajant, Division of Molecular Internal Medicine, Department of Internal Medicine II, University Hospital Würzburg, Roentgenring 11, Wuerzburg 97070, Germany. Tel: + 49931201 71010; Fax: + 49931201 71070; E-mail: harald.wajant@mail.uni-wuerzburg.de Keywords: NFkappaB; TWEAK; TNF; TRAF

Abbreviations: cIAP1/2, cellular inhibitor of apoptosis; $I_{\kappa} B$, inhibitor of kappaB; IKK, $I_{\kappa} B$ kinase; JNK, cJun N-terminal kinase; NF $\kappa B$, nuclear factor kappaB; TNFR1, tumor necrosis factor (TNF) receptor-1; TRAF1/2, TNF receptor-associated factor-1/2; TRAIL, TNF-related apoptosis-inducing ligand

Received 26.9.08; revised 20.5.09; accepted 20.5.09; Edited by JP Medema; published online 26.6.09
} 
pathway. ${ }^{4,5} \mathrm{Fn} 14$ expression is significant in many tumor cell lines, but relatively low in most tissue ${ }^{8,14}$ However, Fn14 can be readily induced by FGF and by other growth factors that are released in response to tissue injury. ${ }^{8}$ Accordingly, upregulation of Fn14 has been reported, among others, in the liver on hepatectomy, in the vasculature after vessel damage, in skeletal muscle after intoxication, during glomerulonephritis, in association with liver fibrosis and during collagen-induced arthritis. $^{8,12,15-18}$ The Fn14 expression pattern points to a physiological role of the TWEAK/Fn14 system in tissue repair, and an involvement in pathological hyperplasia and cancer. ${ }^{19}$ In fact, TWEAK supports cell cycle progression and induces a proliferation of progenitor cells of the mesenchymal lineage. ${ }^{16,18,20}$ In further accordance with its proliferative effects, TWEAK inhibits the differentiation of chondrocytes, osteoblasts and myocytes. $7,18,20,21$

Here, we show that soluble TWEAK induces the depletion of the cytosolic TRAF2 pool and impairs RIP ubiquitination and $\mathrm{NF} \kappa \mathrm{B}$ activation on TNFR1 stimulation. Thus, soluble TWEAK inhibits proinflammatory TNF response. Moreover, we found that TWEAK priming enhances the induction of apoptosis and necrosis by TNF. Finally, we provide initial evidence that the TRAF2-interacting NF $\kappa$ B target, TRAF1, rescues proinflammatory TNFR1 signaling from the inhibitory effect of soluble TWEAK.

\section{Results}

TWEAK induces translocation of TRAF2 into a triton X-100-insoluble compartment. TWEAK activates the alternative $\mathrm{NF} \kappa \mathrm{B}$ pathway and the latter in turn is associated with the degradation of TRAF2 and TRAF3. ${ }^{22}$ We therefore asked whether TRAF2-dependent functions in TNFR1 signaling could be modulated by TWEAK. First, we analyzed in a panel of seven Fn14-expressing tumor cell lines (Figure 1a) the effect of a soluble trimeric Flag-tagged variant of TWEAK on TRAF2 expression. After stimulation with Flag-TWEAK for 6 or $18 \mathrm{~h}$, we observed in all cell lines a reduction of TRAF2 in the triton X-100-soluble fraction, whereas in total cell lysates, there was no or only a modest decrease in TRAF2 (Figure 1b). A refined kinetic analysis of the TWEAK-induced depletion of TRAF2 from the triton X-100-soluble fraction in HT29 and HeLa80 cells revealed that TRAF2 redistribution into the triton $X-100$-insoluble compartment becomes detectable after $15 \mathrm{~min}$ and reaches a plateau after 4-8 h (Figure 1c). When triton X-100 lysates were separated by sucrose density gradient centrifugation, the huge majority of TRAF2 resided in the detergent-soluble fraction in unstimulated cells, whereas in TWEAK-stimulated cells, a significant increase of TRAF2 was found in fractions containing the established lipid raft marker, flotillin
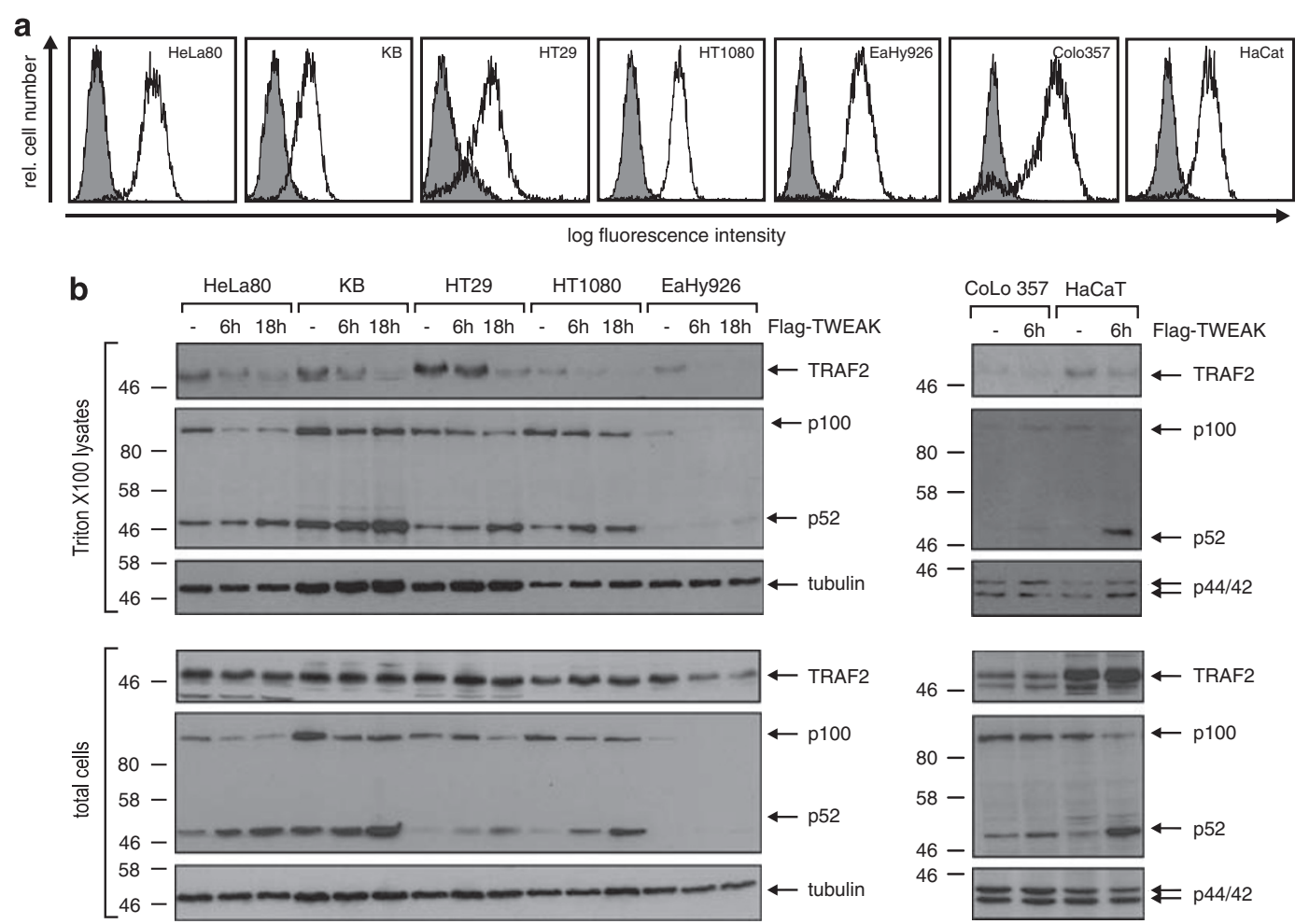

Figure 1 TWEAK induces translocation of TRAF2 into a triton X-100-insoluble membrane fraction. (a) Analysis of cell surface expression of Fn14 by flow cytometric analysis (Fn14, no filling; isotype control, gray filling). (b) The indicated cell lines were stimulated for 6 and $18 \mathrm{~h}$ with $200 \mathrm{ng} / \mathrm{ml}$ of Flag-TWEAK and were either directly boiled in Laemmli sample buffer or lysed in triton X-100 buffer. Cleared samples were finally analyzed by western blotting for the presence of TRAF2, p100/p52, and tubulin or ERK p42/44 was used as loading controls. (c) HeLa80 and HT29 cells were stimulated with $200 \mathrm{ng} / \mathrm{ml}$ of Flag-TWEAK for the indicated times and the triton X-100-soluble compartment, together with the corresponding triton X-100-insoluble pellet, was analyzed by western blotting. (d) HT29 and HeLa80 cells were stimulated with Flag-TWEAK (200 ng/ml) for $6 \mathrm{~h}$ or remained untreated. Triton X-100 lysates were subjected to cell fractionation by sucrose gradient centrifugation and were analyzed by western blotting with respect to the indicated proteins. The upper fraction (no. 1) corresponding to the lowest sucrose density represents the detergent-insoluble fraction containing microdomains and lipid rafts, as is evident from the lipid raft marker, flotillin. The lowest, detergent-soluble fraction (no. 4) contained the majority of total protein, particularly non-lipid raft receptors such as transferrin receptor (TfR). Molecular weight markers are indicated to the left of the blots 


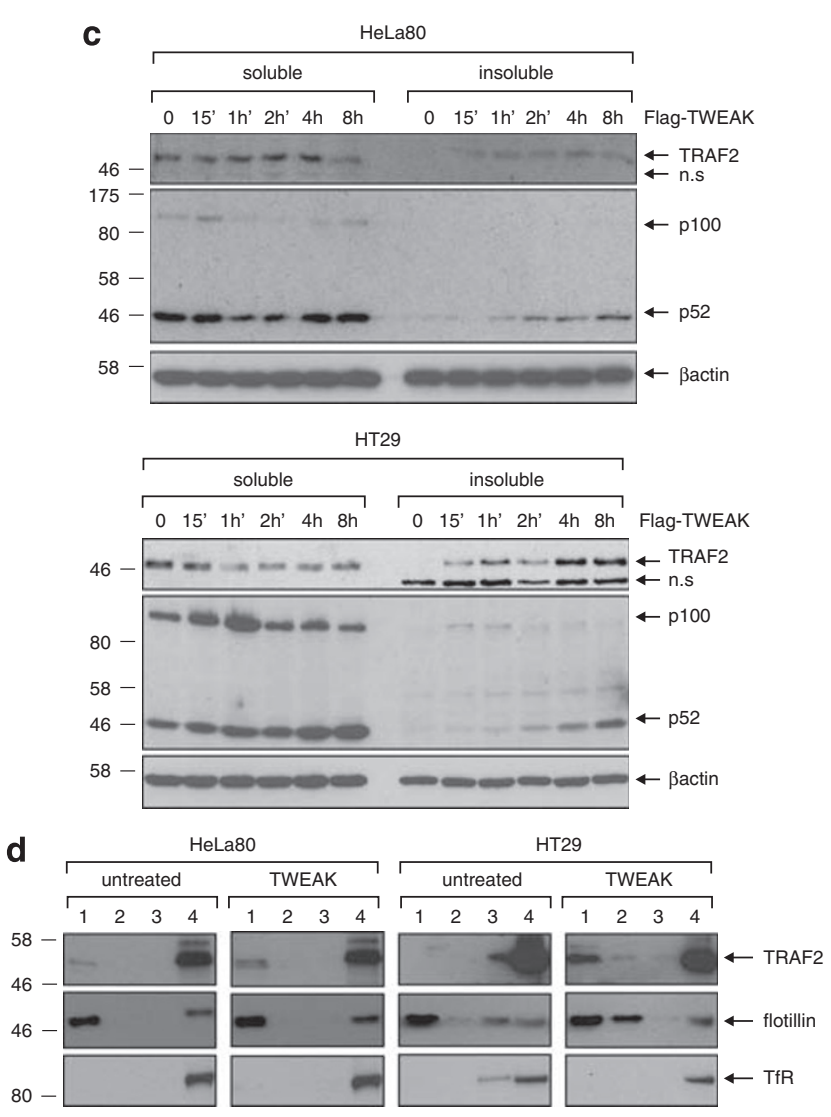

Figure 1 Continued

(Figure 1d). In accordance with the known inhibitory role of TRAF2 in the alternative NF $\kappa$ B-signaling pathway, stimulation with TWEAK also resulted in p100 processing to p52 (Figure 1b and c). Moreover, TWEAK-induced processing of $\mathrm{p} 100$ corresponded to a strong increase of p52 in the triton X-100-insoluble fraction, which also contains nuclear proteins (Figure 1c). Thus, depletion of the cytoplasmic, triton X-100-soluble TRAF2 pool, in the absence of significant net changes of total TRAF2, seems to be sufficient for triggering p100 processing.

TWEAK inhibits the TNFR1-induced activation of NF $\kappa$ B and JNK. Owing to the crucial role of TRAF2 in the TNFR1induced activation of $\mathrm{NF} \kappa \mathrm{B}$ and $\mathrm{JNK},{ }^{23,24}$ we next analyzed the activation of the corresponding signaling pathways by TNF in untreated and TWEAK-pretreated cells. In all cell lines analyzed, TNF induced phosphorylation of inhibitor of kappaB $\left(I_{\kappa} \mathrm{B}\right) \alpha$ and its subsequent degradation within 3-10 min, indicative for the activation of the classical NF $\kappa$ B pathway (Figure 2a). In all these cases, pretreatment with TWEAK resulted to a varying extent in a reduction and/or delay of $\mathrm{I} \kappa \mathrm{B} \alpha$ phosphorylation and degradation. To further prove that the observed effects correspond to a reduced nuclear translocation of p65, the nuclear extracts were analyzed. The treatment with TWEAK resulted in no detectable increase in nuclear p65, but in accordance with the activation of the non-canonical $\mathrm{NF}_{\kappa} \mathrm{B}$ pathway, there was a strong increase in nuclear p52 (Figure 2b). The stimulation of TNFR1 led to a nuclear translocation of p65 within $10 \mathrm{~min}$ in HeLa80 cells, but upon priming with TWEAK, this event was significantly attenuated (Figure $2 b$ ). To verify that the attenuated response of the classical $\mathrm{NF}_{\kappa} \mathrm{B}$ pathway toward TNFR1 activation translates into a reduced upregulation of $N F_{\kappa} \mathrm{B}$-regulated genes, we analyzed the production of the $\mathrm{NF} \kappa \mathrm{B}$ target, IL8, and the synthesis of a destabilized GFP variant encoded by a $\mathrm{NF}_{\kappa} \mathrm{B}$ reporter plasmid. In all cell lines investigated, TNF-induced IL8 production was reduced after TWEAK priming by $10-50 \%$ (Figure $2 \mathrm{c}$ ). The TNF-induced upregulation of the $\mathrm{NF}_{\kappa} \mathrm{B}$-regulated destabilized GFP variant was even more strongly inhibited in TWEAK-primed cells than was the IL8 production (Figure $2 \mathrm{c}$ and d). In accordance with its known low capability to activate the classical $\mathrm{NF}_{\kappa} \mathrm{B}$ pathway, TWEAK treatment alone induced no or only weak IL8 production and also had only a minor effect on the expression of the $\mathrm{NF}_{\kappa} \mathrm{B}$ reporter gene (Figure $2 \mathrm{c}$ and $\mathrm{d}$ ). The rapid and transient activation of JNK by TNF was also inhibited by TWEAK pretreatment (Figure 2a, Supplementary Figure S1).

To further prove whether TWEAK stimulation and depletion of cytosolic TRAF2 interferes with early events in TNFR1 signaling, we analyzed the TNFR1 signaling complex formation. In accordance with the TWEAK-induced reduction in cytosolic TRAF2, we observed a significant, but only partial, decrease in the amount of TNFR1-associated TRAF2 in TWEAK-prestimulated cells. However, more intriguing was the finding that slower migrating, modified RIP species, which are indicative of an $\mathrm{I} \kappa \mathrm{B}$ kinase (IKK)-stimulating TNFR1 signaling complex, were almost absent in the immunoprecipitates derived from TWEAK-pretreated cells (Figure 2e). Thus, priming with TWEAK interfered with the function and composition of the TNFR1 signaling complex upstream of IKK activation.

TWEAK sensitizes cells for apoptosis and necrosis induction by TNFR1. Next, we analyzed the effect of TWEAK on TNFR1-induced cell death. We observed that TWEAK prestimulation strongly sensitizes cells for TNF-induced killing (Figure 3a, 2nd column and b). In contrast, TNF-related apoptosis-inducing ligand (TRAIL)induced cell death remained practically unaffected by TWEAK (Figure 3a, 3rd column). Notably, robust cell death induction by TNF and TNF/TWEAK, and also by TRAIL, required sensitization with cycloheximide in all cell lines investigated in Figure 1. The effect of the latter has mainly been traced back to the downregulation of the short-lived caspase-8 inhibitory FLIP proteins (for example, Leverkus et al., ${ }^{25}$ Wajant et al., ${ }^{26}$ Fulda et al., ${ }^{27}$ Siegmund et al. ${ }^{28}$ ). To prove that TWEAK also enhances TNF-induced cell death in cells that are readily TNF sensitive in the absence of cycloheximide ( $\mathrm{CHX}$ ), we analyzed Kym-1 cells. Kym-1 cells not only rapidly undergo robust apoptosis in response to death receptor stimulation without sensitization with $\mathrm{CHX}$, but are also killed by a prolonged stimulation with TWEAK $(>12 \mathrm{~h})$ by the induction of endogenous TNF and subsequent TNFR1-mediated apoptosis. ${ }^{14,29}$ We therefore analyzed the TNF-TWEAK cross talk in a time frame of $8 \mathrm{~h}$ in which TWEAK-triggered apoptosis has no major role. Under these conditions, the TNFR1-specific TNF mutant induced 
apoptosis with an ED50 value of approximately $10 \mathrm{ng} / \mathrm{ml}$, but only when cells were primed with TWEAK of $0.1 \mathrm{ng} / \mathrm{ml}$; thus a 100 -fold lower concentration was sufficient for killing half of the cells (Figure $3 \mathrm{c}$ ). TWEAK priming, however, had no effect on TRAIL-induced cell death in $\mathrm{Kym}-1$ cells (Figure $3 \mathrm{~d}$ ). A TWEAK-mediated enhancement of cell death induced by a TNFR1-specific TNF mutant in Kym-1 cells was also evident with prolonged incubation times, when the interfering effect
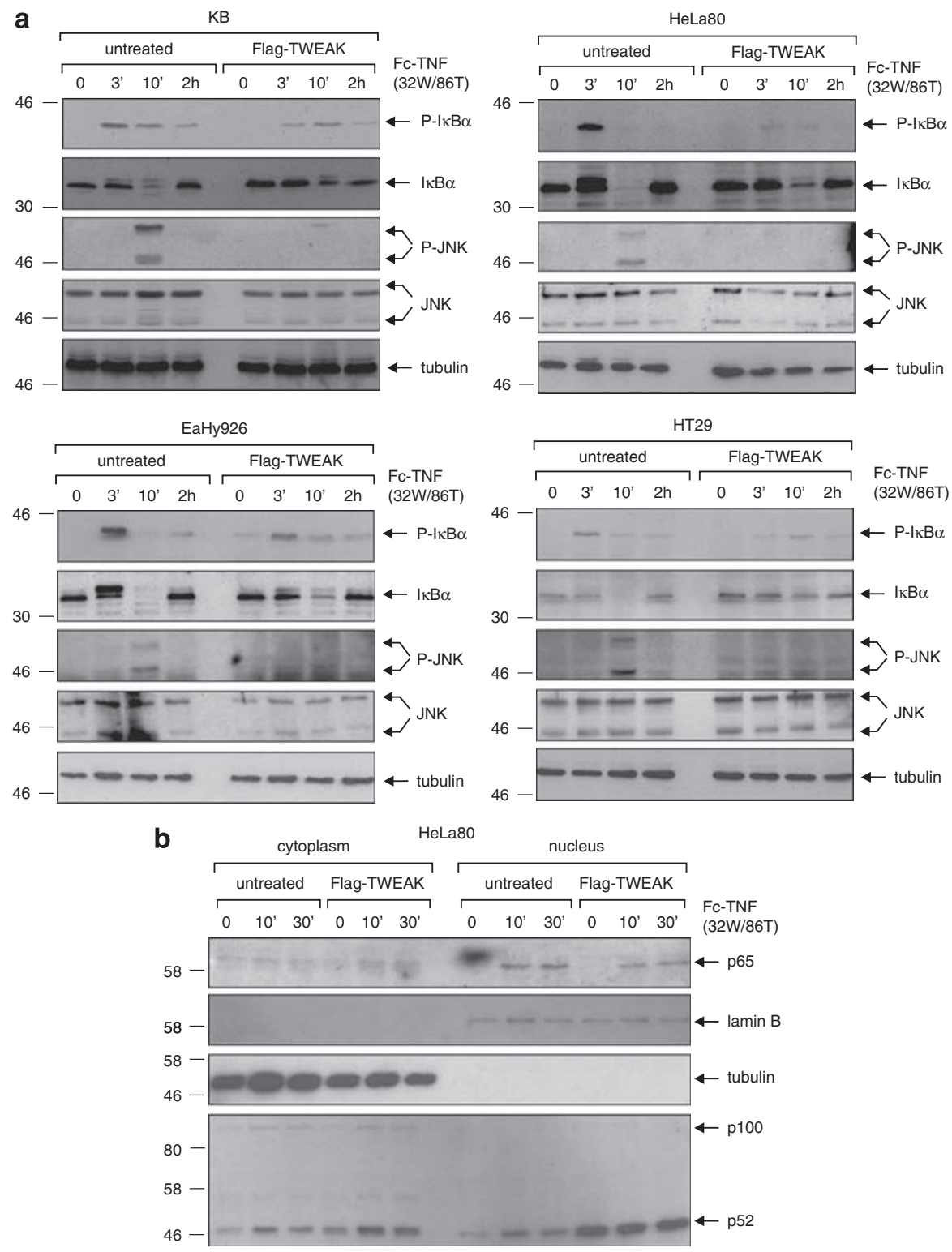

Figure 2 TWEAK inhibits the TNFR1-mediated activation of NF $\kappa$ B and JNK. (a) The indicated cell lines were pre-stimulated with Flag-TWEAK (200 $\mathrm{ng} / \mathrm{ml})$ for $6 \mathrm{~h}$ or remained untreated, and were then stimulated for $0,3,10$ and $120 \mathrm{~min}$ with the TNFR1-specific TNF mutant, Fc-TNF-32W/86T ( $50 \mathrm{ng} / \mathrm{ml})$. Activation of the NF $\kappa$ B and JNK pathways was analyzed by western blotting using antibodies specific for phospho-JNK, the activated form of JNK, phospho-I $\kappa \mathrm{B} \alpha$, which is indicative for the activation of the IKK complex, and $I_{\kappa} B \alpha$, allowing to follow the degradation of this inhibitory protein. The detection of total JNK and tubulin served as loading controls. (b) Untreated and FlagTWEAK-primed ( $200 \mathrm{ng} / \mathrm{ml}$, overnight) HeLa80 cells were stimulated for indicated times with $50 \mathrm{ng} / \mathrm{ml}$ of Fc-TNF-32W/86T. Cytoplasmic and nuclear fractions were isolated and probed for the presence of p65, p100 and p52 by western blotting. As a control, nuclear and cytoplasmic fractions were analyzed with respect to the marker proteins, lamin B (nuclear) and tubulin (cytoplasmic). (c) Cells were pre-stimulated overnight with $200 \mathrm{ng} / \mathrm{ml}$ Flag-TWEAK (black bars) or remained untreated (open bars). The cell culture medium was changed to minimize the contribution of constitutive IL8 production and the cells were stimulated for $6 \mathrm{~h}$ with $50 \mathrm{ng} / \mathrm{ml}$ TNF. Supernatants were removed and the relative IL8 content was determined by ELISA. According to student's T-test, the reduced TNF-induced IL8 production in TWEAK-primed cells was significant or highly significant in all cell lines tested (Colo357, $P<0.0001$; HeLa80, $P=0.0015 ; \mathrm{KB}, P=0.014 ; \mathrm{HT} 1080, P=0.037$; HaCat, $P=0.009$ ), with the exception of EaHy926 and HT29. (d) HeLa80 cells were transiently transfected with a NF $\kappa$ B-regulated destabilized GFP reporter plasmid. Next day, the transfectants were primed overnight with $200 \mathrm{ng} / \mathrm{ml}$

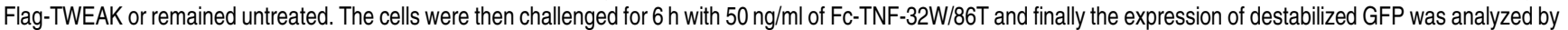
FACS. (e) TNFR1 signaling complexes were induced in untreated and Flag-TWEAK (200 ng/ml, $6 \mathrm{~h}$ )-pretreated HeLa cells by stimulation with $200 \mathrm{ng} / \mathrm{ml} \mathrm{Fc}-\mathrm{TNF}-32 \mathrm{~W} / 86 \mathrm{~T}$ for 3 and $10 \mathrm{~min}$. Fc-Flag-TNF-associated proteins were immunoprecipitated with protein $\mathrm{G}$ sepharose and analyzed together with the corresponding lysates for the presence of the indicated proteins by western blotting. Lysates of untreated cells supplemented with $50 \mathrm{ng}$ Fc-TNF-32W/86T or $50 \mathrm{ng}$ Fc-TNF-32W/86T plus $50 \mathrm{ng}$ Flag-TWEAK were immunoprecipitated as controls. Molecular weight markers are indicated to the left of the blots 

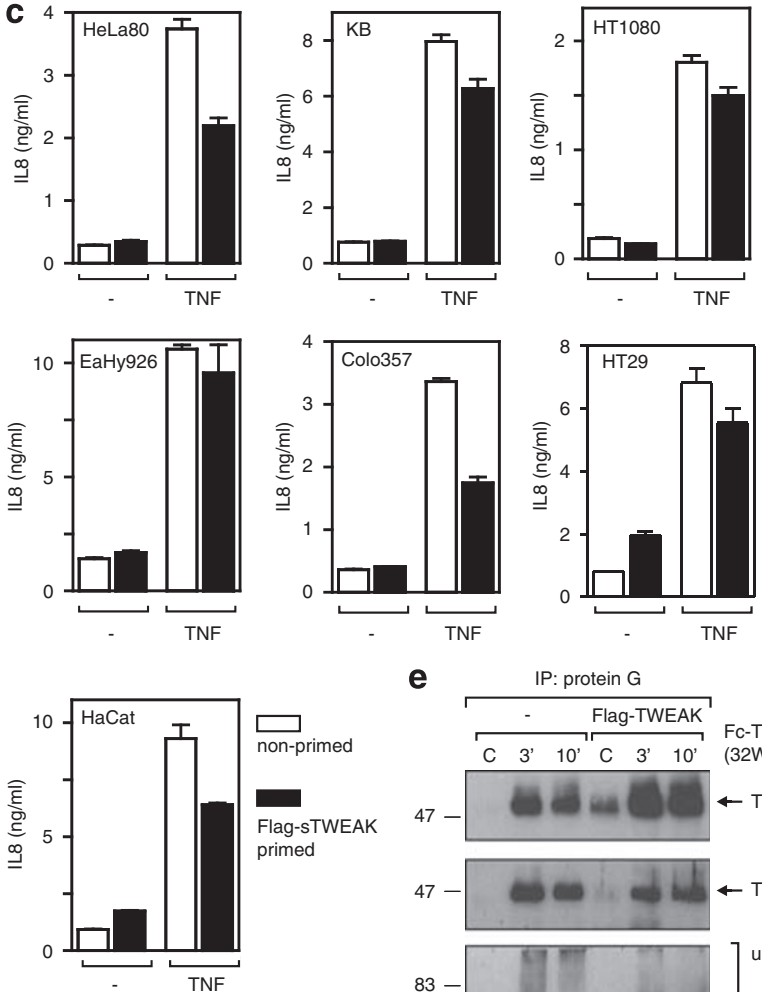

e

IP: protein $\mathrm{G}$

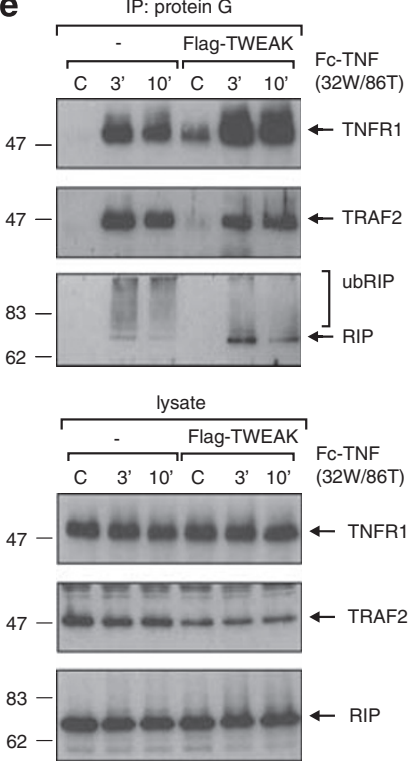

Figure 2 Continued

of TWEAK-induced endogenous TNF was blocked by soluble TNFR2-Fc (Figure 3e). TWEAK-primed cells also showed reduced TNFR1-induced $\mathrm{I} \kappa \mathrm{B} \alpha$ phosphorylation and delayed degradation of $\mathrm{I} \kappa \mathrm{B} \alpha$ (Figure $3 \mathrm{f}$ ), indicating an attenuated $\mathrm{NF} \kappa \mathrm{B}$ signaling. As TNF- and TRAIL-induced apoptosis converge at the level of FADD and caspase-8, the selectivity of the apoptotic TNF-TWEAK cross talk suggests that TWEAK targets a receptor-proximal event in TNFR1 signaling and is thus in good accordance with the observed inhibitory effect on TNF-induced RIP ubiquitination.

TNF can kill cells not only by caspase-dependent apoptosis but also by caspase-independent necrosis. ${ }^{30,31}$ To prove whether TWEAK enhances both modes of TNF-induced cell death, we analyzed HeLa80 and HT29 cells in more detail. TNF-induced cell death fully relies on caspase activation and 'classical' apoptosis in HeLa80 cells. ${ }^{32}$ In sensitized HT29 cells, however, TNF and other death ligands not only trigger caspase activation but also necrotic cell death. ${ }^{30}$ In confirmation of the cited reports, we found that the caspase inhibitor,
z-VAD-fmk, completely rescued HeLa80 cells from TNFinduced cell death, whereas it failed and even slightly enhanced the TNF-induced killing of HT29 cells (Figure $4 a$ and b). Furthermore, TNF-stimulated TWEAKpretreated cells responded in the same way to treatment with z-VAD-fmk. Thus, HeLa80 cells were again rescued whereas HT29 cells were still very sensitive, despite successful blockage of caspase activation (Figure $4 \mathrm{a}-\mathrm{c}$ ). To further substantiate the idea that TNF induces necrosis in TWEAKprimed HT29 cells, we take advantage of the RIP inhibitor, necrostatin-1, which interferes with death receptor-induced RIP-mediated necrosis. ${ }^{33}$ Although necrostatin-1 showed only a minor effect on the cell viability of TNF-challenged TWEAK-primed HeLa80 cells, it rescued TWEAK-primed HT29 cells from TNF-induced cell death (Figure 4d). Thus, TWEAK can enhance both TNF-induced caspase-dependent apoptosis and TNF-triggered necrosis.

So far, we investigated TWEAK-primed cells, a situation in which TRAF2 was already depleted from the triton X-100soluble compartment, and observed inhibition of TNFR1induced $\mathrm{NF}_{\kappa} \mathrm{B}$ activation and concomitantly enhanced cell death induction. However, this changed when cells were stimulated with TWEAK and TNF at the same time. Upon TWEAK costimulation, there was no obvious inhibition of TNF-induced phosphorylation and degradation of $\mathrm{I} \kappa \mathrm{B} \alpha$, and no significant inhibitory effect $(>10 \% ; P$-value $>0.1)$ on TNFinduced IL8 production (Figure $4 \mathrm{e}$ and $\mathrm{f}$ ). It is evident from $I_{\kappa} \mathrm{B} \alpha$ phosphorylation that TNFR1 stimulation resulted in a transient activation of the IKK complex within 3-10 min (Figures $2 \mathrm{a}$ and $4 \mathrm{e}$ ). This event is thus clearly faster than the TWEAK-induced TRAF2 depletion (Figure 1c). The fact that TWEAK costimulation has practically no effect on TNFinduced $\mathrm{NF}_{\kappa} \mathrm{B}$ activation is, therefore, in good accordance with the kinetics of these effects. The enhancement of TNFinduced cell death by TWEAK was attenuated under costimulatory conditions, but was still very efficient (Figure $4 \mathrm{~g}$ ). In fact, TWEAK stimulation even enhanced cell death induction $1 \mathrm{~h}$ after TNF treatment (Figure $4 \mathrm{~g}$ ). This suggests that TWEAK-induced enhancement of TNFR1mediated cell death is not only related to the inhibition of the anti-apoptotic $\mathrm{NF}_{\kappa} \mathrm{B}$ pathway but also relies on additional mechanisms.

Regulation of TNFR1 signaling by TWEAK in TRAF1expressing HeLa80 cells. Subsequently, we analyzed the effect of TRAF1 expression on the TWEAK-induced inhibition of proinflammatory TRAF2-mediated TNFR1 signaling for several reasons:

- TRAF1 forms heteromers with TRAF2 with high affinity; ${ }^{32,34}$

- TRAF1 is recruited to TNFR1, as well as to the Fn14 signaling complex; $;, 35$

- TRAF1 is regulated by $N F \kappa$ B and modulates the activity of the classical $\mathrm{NF} \kappa \mathrm{B}$ pathway in a receptor-specific manner. ${ }^{36-39}$

As TRAF1 is not expressed in non-stimulated cells, we generated TRAF1 transfectants of HeLa80 cells. To avoid artificial effects related to non-physiological expression levels 
of TRAF1, we screened the transfectants obtained by western blotting and selected clones with TRAF1 expression levels comparable with those reached in TNF-stimulated cells or cells with a constitutive active NF $\kappa$ B pathway, such as HUT78 (Figure 5a). The selected HeLa80-TRAF1 clone showed a reduced depletion of cytosolic TRAF2 after TWEAK stimulation (Figure 5b). TNFR1-induced phosphorylation and degradation of $\mathrm{I} \kappa \mathrm{B} \alpha$ were increased in TWEAK-primed HeLa80-TRAF1 cells compared with that in their TWEAKprimed vector-transfected counterparts (Figure 5c). The a
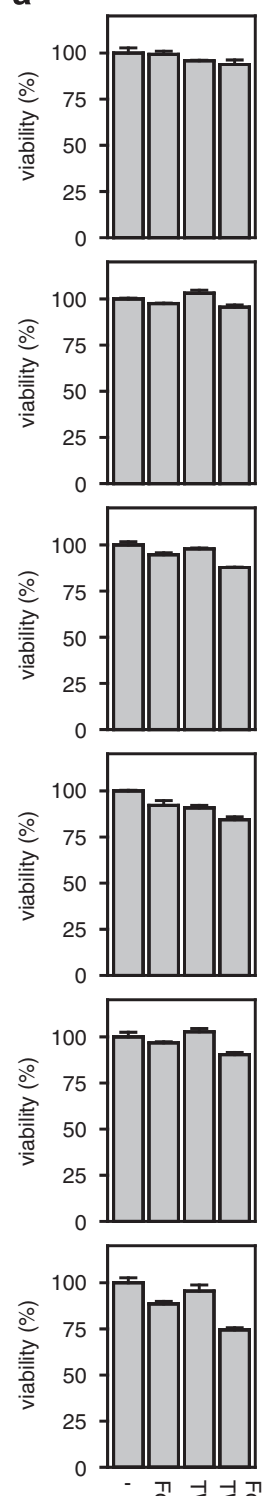

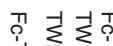

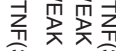
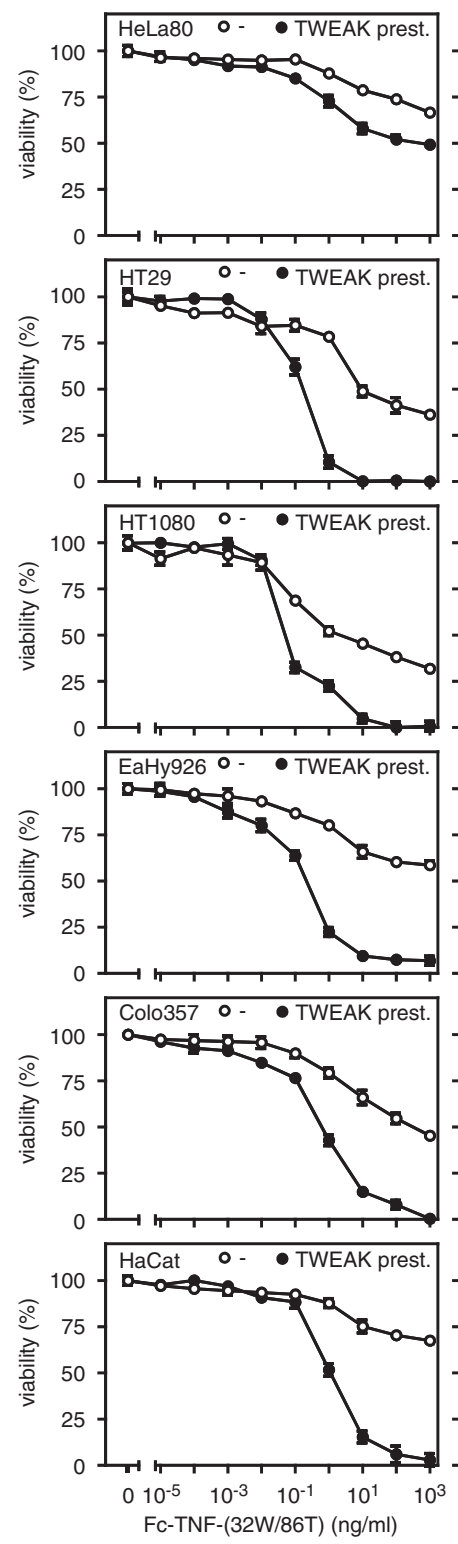
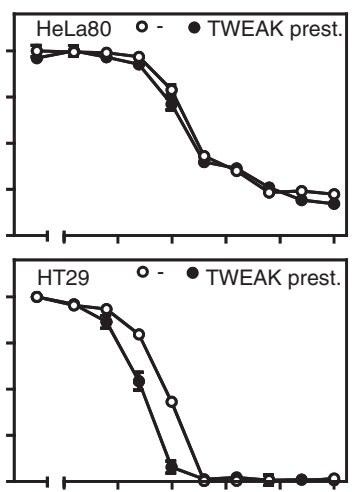

b
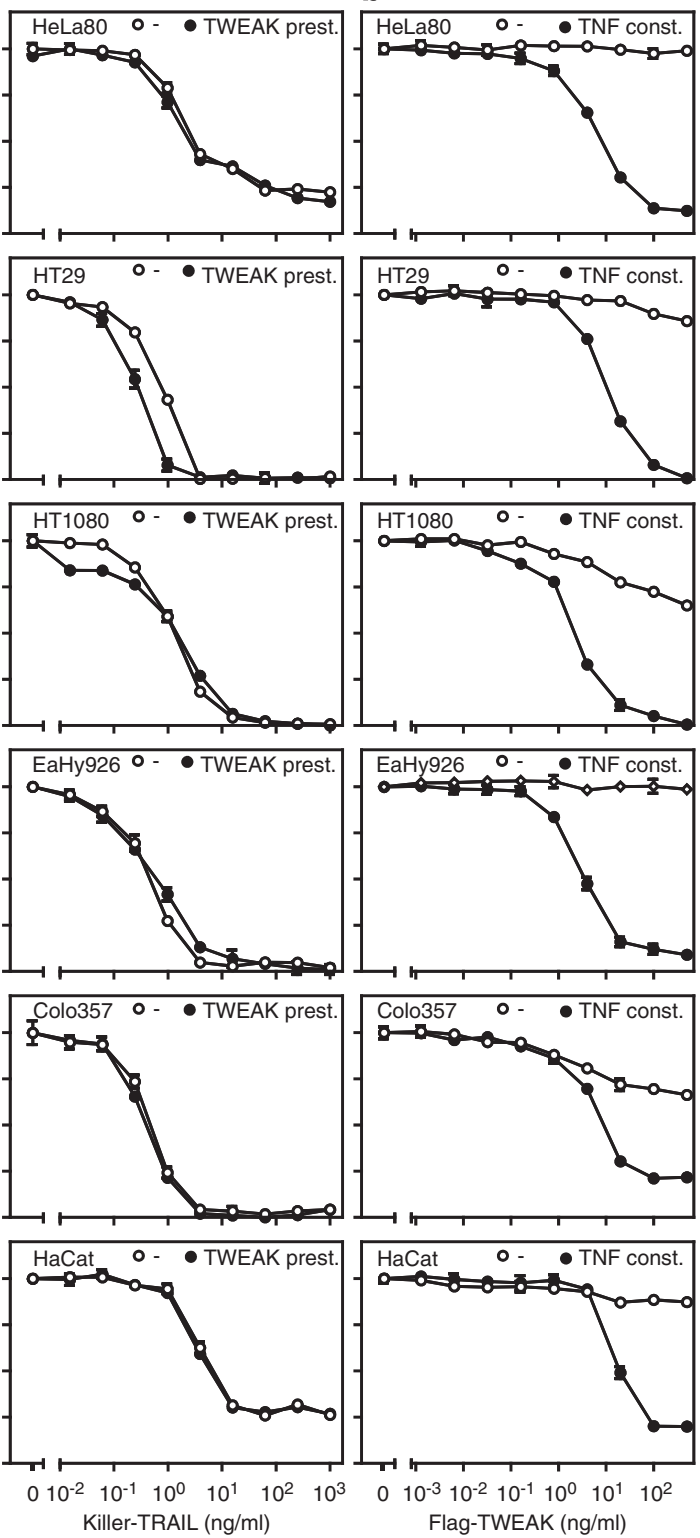

Figure 3 TWEAK enhances TNFR1-induced cell death. (a) The various cell lines were pre-stimulated with Flag-TWEAK (200 $\mathrm{ng} / \mathrm{ml})$ for $6 \mathrm{~h}$ and then stimulated in triplicates with the indicated concentrations of Fc-TNF-32W/86T or Killer-TRAIL in the presence of $2.5 \mu \mathrm{g} / \mathrm{ml} \mathrm{CHX.} \mathrm{Bars} \mathrm{in} \mathrm{the} \mathrm{left} \mathrm{panel} \mathrm{show} \mathrm{the} \mathrm{cytotoxic} \mathrm{effect} \mathrm{of} \mathrm{the} \mathrm{highest}$ concentration $(1 \mu \mathrm{g} / \mathrm{ml})$ of TNF with and without Flag-TWEAK priming in the absence of CHX. (b) The cell lines were stimulated with the indicated concentrations of Flag-

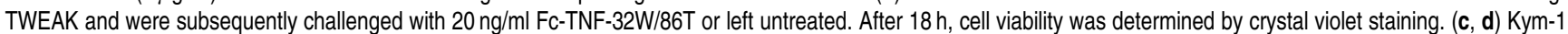
cells were pre-stimulated with Flag-TWEAK $(200 \mathrm{ng} / \mathrm{ml}$ ) for $2 \mathrm{~h}$ and then challenged in triplicates with the indicated concentrations of Fc-TNF-32W/86T (c) or Killer-TRAlL (d) for an additional $6 \mathrm{~h}$. Cell viability was again determined by crystal violet staining. (e) Kym-1 cells were incubated with TNFR2-Fc (4 $\mu \mathrm{g} / \mathrm{ml})$ and stimulated with Flag-TWEAK $(200 \mathrm{ng} / \mathrm{ml})$ for $6 \mathrm{~h}$. Cells were then treated in triplicates overnight with the indicated concentrations of Fc-TNF-32W/86T. Cell viability was again determined by crystal violet staining. (f) Kym-1 cells were primed with Flag-TWEAK (200 ng/ml) for $6 \mathrm{~h}$ or remained untreated. Cells were then stimulated for 0, 3, 10 and 120 min with the TNFR1-specific TNF mutant, Fc-TNF-32W/86T (50 ng/ml), and the presence of phospho- $\mid \kappa B \alpha$ and $I \kappa B \alpha$ was analyzed by western blotting 

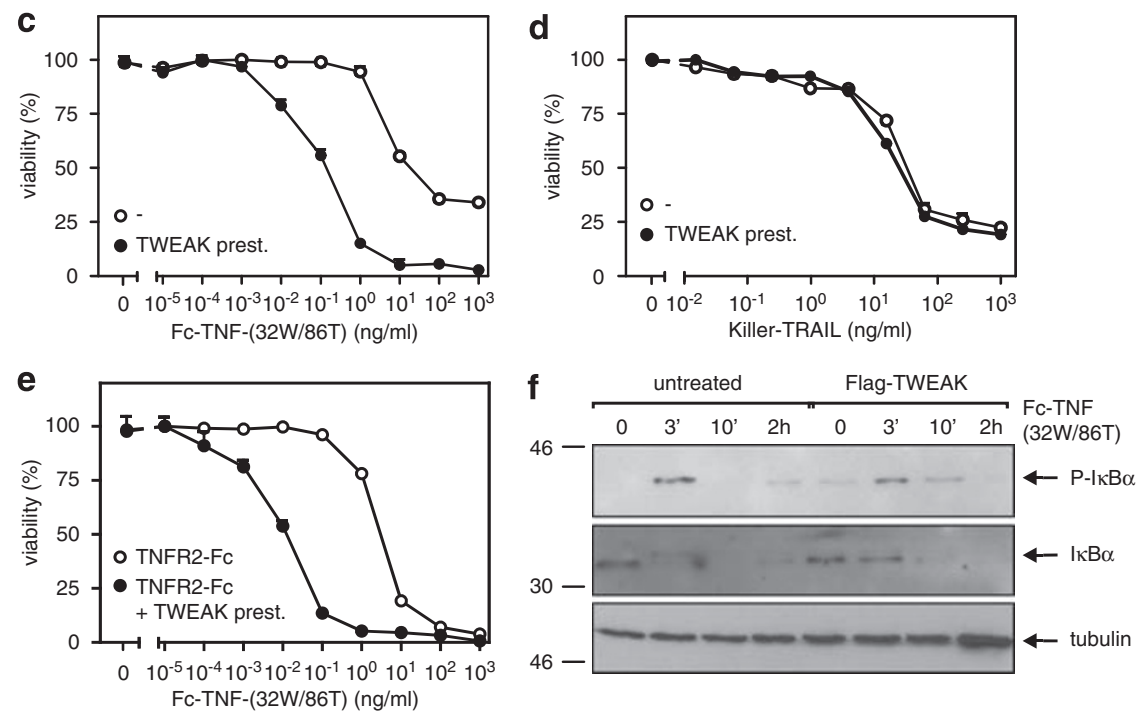

Figure 3 Continued

TRAF1-dependent attenuation of the inhibitory effect of TWEAK on proinflammatory TNFR1 signaling corresponded with an improved TNFR1 signaling complex formation. Thus, under TWEAK-primed conditions, TNF-induced IKK1 recruitment to the TNFR1 signaling complex after $3 \mathrm{~min}$ was enhanced in TRAF1-expressing cells and there was also a partial restoration of RIP ubiquitination (Figure $5 d$ ). Notably, TNF-induced recruitment of TRAF2 to TNFR1 was reduced in cells expressing TRAF1, but instead there was a recruitment of TRAF1 (Figure 5d). Thus, TRAF1 seems to replace TRAF2 in TNFR1 signaling complex formation. We also observed that the inhibitory effect of TWEAK priming on TNFR1-induced IL8 production was diminished in TRAF1-expressing cells (Figure 5e). In accordance with the idea that both inhibition of $\mathrm{NF}_{\kappa} \mathrm{B}$ activation and enhancement of cell death are related to the depletion of TRAF2-containing complexes, we further found a reduced apoptotic cooperation of TNF and TWEAK in TRAF1-expressing cells (Figure 5f). Although TRAF1 expression does not fully rescue TNFR1 signaling in TWEAK-primed cells, the attenuating effects observed by several independent techniques (TNFR1 IP, I $\kappa \mathrm{B} \alpha$ phosphorylation, $\mathrm{I} \kappa \mathrm{B} \alpha$ degradation, IL8 target gene production, viability) clearly indicate that TRAF1 antagonizes TRAF2 depletion/degradation by TWEAK and thereby attenuates its modulating effect on TNFR1 signaling. Thus, we could show that TRAF1, which is itself upregulated by TNF, acts as an inhibitor of the TNF-TWEAK cross talk.

Relevance of TWEAK oligomerization for TRAF2 depletion and p100 degradation. Vince et al. ${ }^{14}$ have shown very recently that TWEAK decreases cellular inhibitor of apoptosis (clAP1) and TRAF2 by lysosomal degradation, resulting in an enhancement of TNF-induced apoptosis. With respect to the enhancement of TNF-induced apoptosis, our observation matches with this study. However, there is a variance between the study by Vince et al. and our experiments with respect to TRAF2 degradation, as we observed no changes in the total
TRAF2 content of TWEAK-stimulated cells. Vince et al. used, in their study, a hexameric human immunoglobulin fusion protein of TWEAK (Fc-TWEAK), whereas we utilized a Flag-tagged trimeric variant of TWEAK. Previously, it was found that some receptors of the TNF receptor superfamily are not or are inadequately activated by soluble trimeric variants of their cognate ligand, but become readily activated by hexameric variants or oligomerized trimers. ${ }^{40}$ Therefore, we compared hexameric, and oligomerized and nonoligomerized trimeric TWEAK with respect to the modulation of TRAF2 expression. As already shown in Figure 1, treatment with Flag-TWEAK resulted in a reduction of the TRAF2 content in the triton X-100 fraction without changes in total TRAF2 (Figures $1 \mathrm{~b}$ and $6 \mathrm{a}$ ). In contrast, in cells challenged with FC-TWEAK or oligomerized Flag-TWEAK, TRAF2 was not only strongly reduced in the triton X-100soluble compartment but was also significantly downregulated in total cell lysates (Figure 6a). Thus, the difference between the data of Vince et al. and our study regarding TRAF2 degradation can be explained by the differential capability of trimeric TWEAK and oligomerized TWEAK to trigger TRAF2 degradation. The oligomerization status of TWEAK has no major impact on the dose dependency of p100 processing (Figure 6b), suggesting that TRAF2 depletion from the triton $\mathrm{X}-100$-soluble pool without degradation is already sufficient for the activation of the alternative $\mathrm{NF} \kappa \mathrm{B}$ pathway. Likewise, there was no major difference in the capability of Fc-TWEAK, FlagTWEAK and oligomerized Flag-TWEAK to enhance TNFinduced cell death (Figure 6c) and to attenuate TNFR1induced $\mathrm{NF}_{\kappa} \mathrm{B}$ signaling (data not shown). In particular, soluble TWEAK trimers that have been collected from the supernatant of membrane TWEAK-expressing cells enhanced TNF-induced cell death just as well as did Flag-tagged TWEAK (Figure 6d).

TWEAK inhibits proinflammatory TNFR1 signaling in synovial fibroblasts. It has been recently reported that primary murine embryonal fibroblasts (MEFs) are resistant 

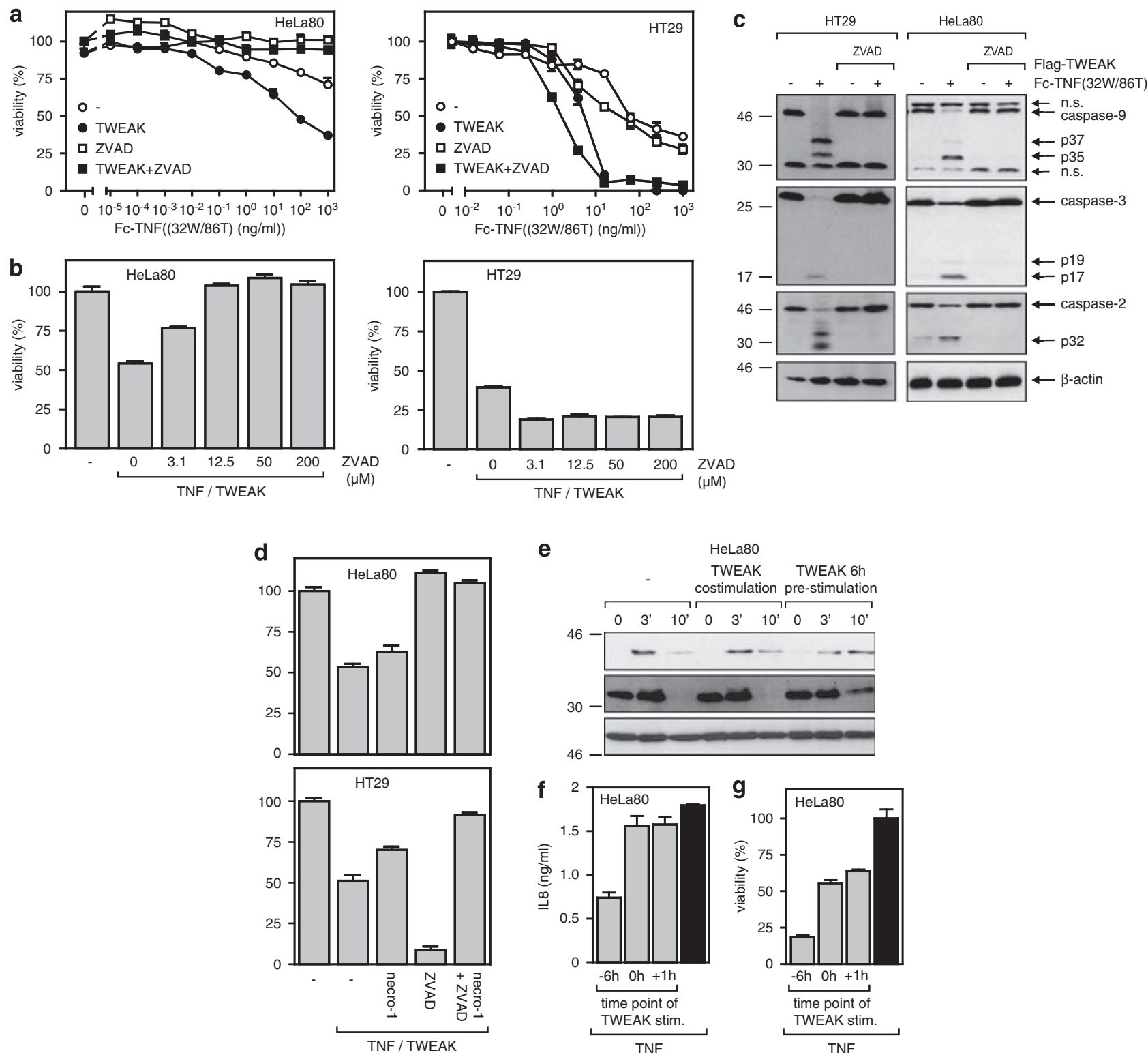

eLa80

WWAK TWEAK $6 \mathrm{~h}$ stimulation pre-stimulation 3' $10^{\prime} \quad 0 \quad 3$ 3 $^{\prime} 10^{\prime}$ TNF

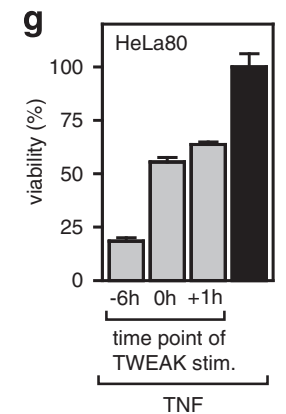

Figure 4 TWEAK sensitizes for TNFR1-induced caspase-independent cell death. (a) HT29 and HeLa80 cells were primed with Flag-TWEAK (200 ng/ml) for $6 \mathrm{~h}$ or remained untreated. Cells were then sensitized with $\mathrm{CHX}(2.5 \mu \mathrm{g} / \mathrm{ml})$ and were challenged in triplicates with the indicated concentrations of Fc-TNF-32W/86T in the presence or absence of $100 \mu \mathrm{M} \mathrm{z-VAD-fmk}$ and were analyzed after an overnight incubation with respect to their viability. (b) Cells were pre-stimulated with Flag-TWEAK (200 ng/ml, $6 \mathrm{~h}$ ), sensitized with $\mathrm{CHX}$ and stimulated overnight with Fc-TNF-32W/86T $(50 \mathrm{ng} / \mathrm{ml})$ in the presence of the indicated concentration of z-VAD-fmk. Finally, viability was determined by crystal violet staining. The protective effect of ZVAD on HeLa80 cells, as well as its sensitizing effect on HT29 cells, was in all cases highly significant (student's $T$-test $P<0.0001$ ). (c) Cells were pretreated with a mixture of Flag-TWEAK and TNF in the presence of CHX as in ' $a$ ' and were harvested after $5 \mathrm{~h}$ to analyze the processing of the indicated caspases by western blotting. (d) TWEAK-primed CHX-sensitized HT29 and HeLa80 cells were incubated for $1 \mathrm{~h}$ with the indicated mixtures of z-VAD-fmk

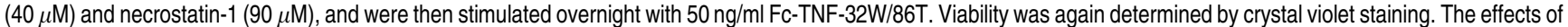
necrostatin-1 and ZVAD on TNF/TWEAK-induced cell death were in all cases highly significant (student's $T$-test $P<0.0002$ ). (e) Cells were challenged with Fc-TNF-32W/86T $(50 \mathrm{ng} / \mathrm{ml})$ for the indicated times upon TWEAK priming $(200 \mathrm{ng} / \mathrm{ml}, 6 \mathrm{~h})$, together with TWEAK ( $200 \mathrm{ng} / \mathrm{ml})$, or without further treatment, and analyzed by western blotting for the phosphorylation and degradation of $I_{\kappa} \mathrm{B} \alpha$. Positions and molecular weight (in $\mathrm{kDa}$ ) of protein markers are indicated. (f, $\mathbf{g}$ ) Cells were challenged with Fc-TNF-32W/86T $(50 \mathrm{ng} / \mathrm{ml})$ for $6 \mathrm{~h}$ or together with $\mathrm{CHX}$ overnight, before or after TWEAK stimulation. Cells were than analyzed with respect to IL8 production (f) and viability (g). Data were normalized to the values of the samples treated only with TNF. The inhibitory effect on IL8 production and viability observed in the TWEAK pre-stimulated groups ( $-6 \mathrm{~h}$ ) were highly significant. Under costimulatory $(0 \mathrm{~h})$ or post-stimulatory conditions $(+1 \mathrm{~h})$, there was a significant difference only with respect to cell death induction, but not in IL8 production (student's $T$-test $P<0.0002$ )

against cell death induction by mixtures of TNF and TWEAK, whereas transformed MEFs are sensitive. ${ }^{14}$ To get a first impression whether the TNF-TWEAK cross talk is possibly restricted to transformed cells, we analyzed primary synovial fibroblasts. We observed no induction of cell death by TNF, irrespective of whether cells were primed or not with FlagTWEAK. There was also no TNF/TWEAK-induced cytotoxicity when cells were sensitized with $\mathrm{CHX}$ (data not shown). 
However, we observed a rapid and transient phosphorylation of $\mathrm{I} \kappa \mathrm{B} \alpha$ and JNK by TNF, and both events were significantly downregulated in cells primed for $6 \mathrm{~h}$ with Flag-TWEAK (Figure 7). Thus, proinflammatory TNFR1 signaling is also subjected to inhibition by TWEAK in primary cells, although this is obviously not necessarily sufficient for cell death induction.

\section{Discussion}

The adaptor protein, TRAF2, has multiple functions in TNFR1 signaling. For example, TRAF2 recruits the IKK complex and clAPs to the TNFR1 signaling complex and is thus necessary for activation of the classical $N F \kappa B$ pathway, ${ }^{23,41}$ which regulates, besides proinflammatory effectors, a variety of survival proteins such as FLIP, Bcl2, Bfl1, MnSOD and
clAP2. ${ }^{1}$ A complex of TRAF2 with clAP1, clAP2 and TRAF1 has furthermore been implicated in the inhibition of TNFR1induced activation of caspase-8. ${ }^{42}$ We and others have found in previous studies that TNFR2 induces the translocation of TRAF2 from the cytosol into a triton X-100-insoluble compartment, where it is prone to proteolytic degradation by the proteasome and/or by the lysosome. ${ }^{14,32,43-50}$ Consequently, TNFR2 activation results in the inhibition of TNFR1induced $\mathrm{NF}_{\kappa} \mathrm{B}$ activation and enhancement of caspase-8 and cell death induction. Thus, the balance between TNFR1 and TNFR2 activity has a pivotal role in the quality of cellular TNF responses. ${ }^{1}$

Here, we demonstrate that TWEAK modulates TNFR1 signaling in a similar manner to TNFR2. TWEAK treatment resulted in a variety of cell lines in the depletion of cytosolic

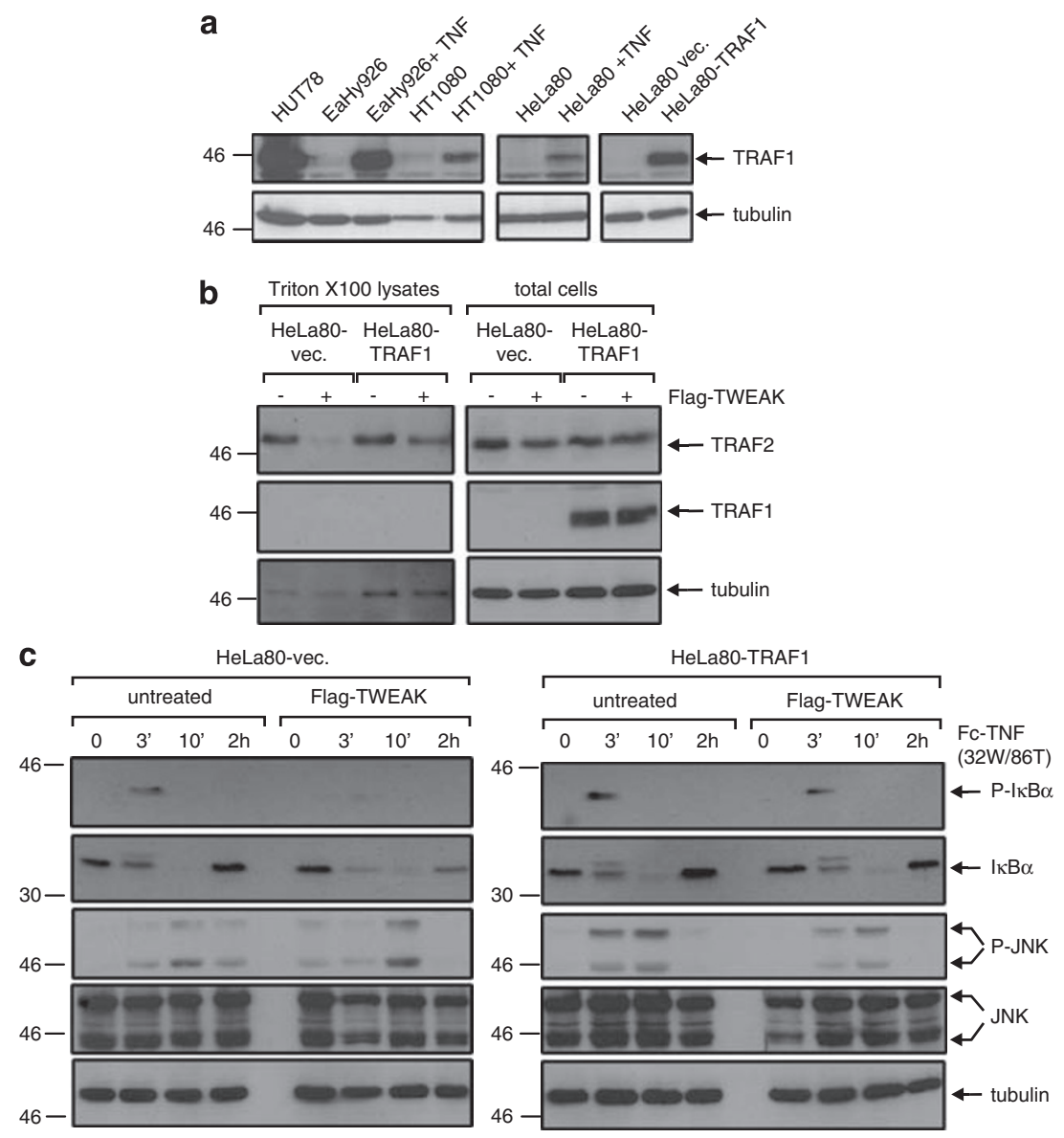

Figure 5 TRAF1 inhibits TWEAK-induced TRAF2 depletion and rescues TRAF2-dependent TNFR1 signaling from TWEAK-induced inhibition. (a) The TRAF1 expression of the indicated cell lines and HeLa80 transfectants was determined in whole cell lysates by western blot analysis. To boost the NF $k$ B-dependent expression of endogenous TRAF1, samples of cells that were previously stimulated with TNF for $18 \mathrm{~h}$ were included. Please note that the western blot data shown are directly comparable as they were derived from different parts of the same X-ray film from a single blot. (b) Vector-transfected HeLa80 cells and the corresponding TRAF1 transfectant were stimulated with $200 \mathrm{ng} / \mathrm{ml}$ Flag-TWEAK for $6 \mathrm{~h}$. Triton X-100 lysates and whole cell lysates were then analyzed by western blotting for the presence of the indicated proteins. (c) Control and TRAF1-expressing HeLa80 transfectants were treated with $200 \mathrm{ng} / \mathrm{ml}$ Flag-TWEAK or remained untreated for $6 \mathrm{~h}$, and were subsequently analyzed with respect to Fc-TNF$32 \mathrm{~W} / 86 \mathrm{~T}$-induced $(50 \mathrm{ng} / \mathrm{ml}$ ) activation of $\mathrm{NF} \kappa \mathrm{B}$ by western blotting. (d) HeLa80-vec and HeLa80-TRAF1 cells were pre-stimulated with Flag-TWEAK (200 ng/ml) for $6 \mathrm{~h}$ or remained untreated. Cells were then challenged for 3 or 10 min with $200 \mathrm{ng} / \mathrm{ml} \mathrm{Fc-TNF}(32 \mathrm{~W} / 86 \mathrm{~T})$ and proteins associated with Fc-TNF(32W/86T) were isolated with protein $\mathrm{G}$ agarose beads, and immunoblots of protein $\mathrm{G}$ precipitates and lysates were probed with antibodies recognizing the indicated proteins. As a control ('C'), lysates of untreated cells were supplemented with $50 \mathrm{ng}$ Fc-TNF-32W/86T plus $50 \mathrm{ng}$ Flag-TWEAK, and were used for immunoprecipitation. (e) The indicated cells were pre-stimulated overnight with $200 \mathrm{ng} / \mathrm{ml}$ of Flag-TWEAK (black bars) or remained untreated (open bars). After exchange of the cell culture, medium cells were challenged for $6 \mathrm{~h}$ with $50 \mathrm{ng} / \mathrm{ml} \mathrm{Fc}$ TNF(32W/86T) and IL8 production was determined by ELISA. (f) Cells were stimulated in triplicates with the indicated combinations of Flag-TWEAK (200 ng/ml) and Fc$\mathrm{TNF}(32 \mathrm{~W} / 86 \mathrm{~T})$ in the presence of $\mathrm{CHX}(2.5 \mu \mathrm{g} / \mathrm{ml})$. The next day, cell viability was determined by crystal violet staining and the data obtained were normalized according to the corresponding control samples that had not received TNF. Molecular weight markers are indicated to the left of the blots 

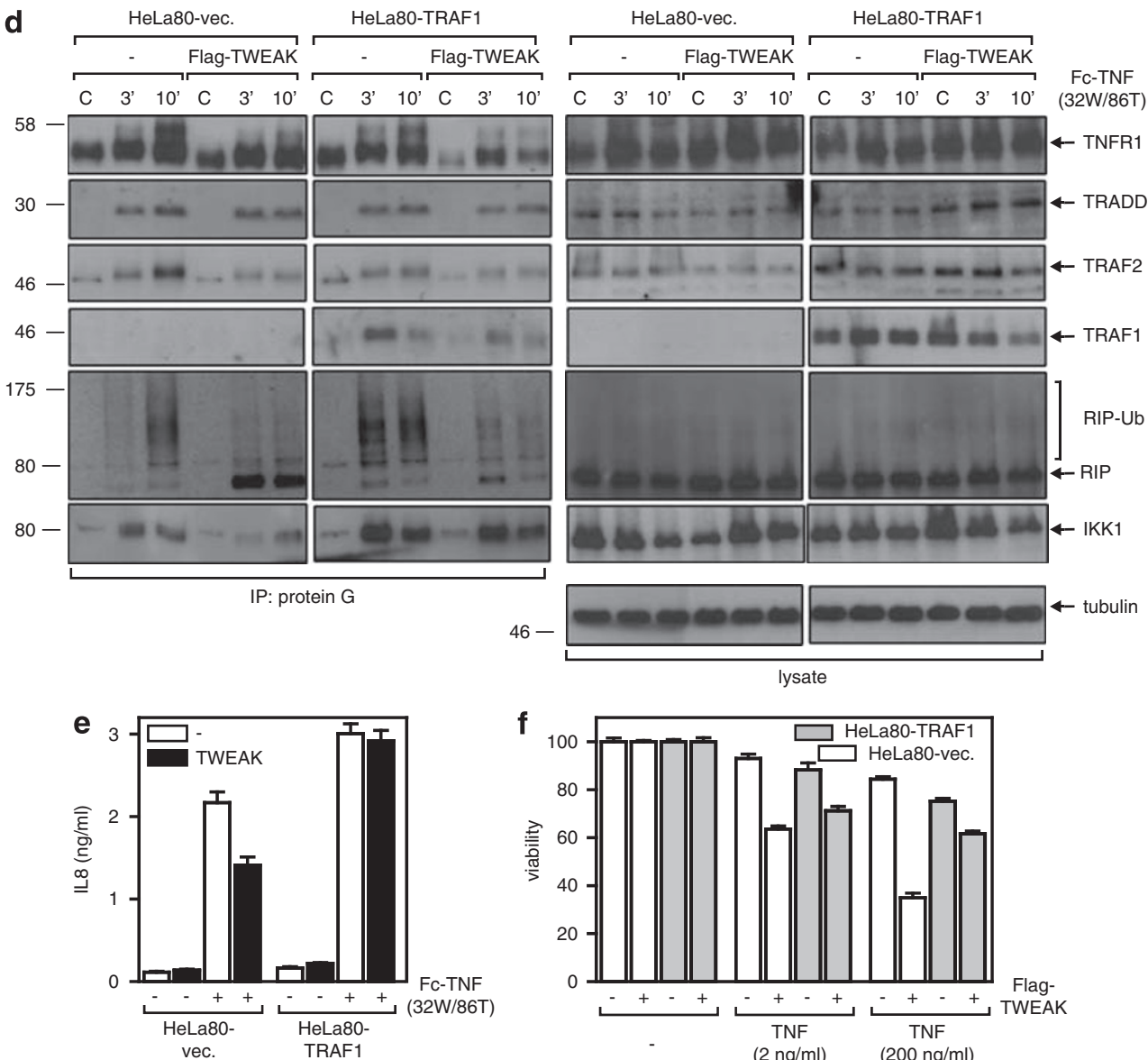

Figure 5 Continued

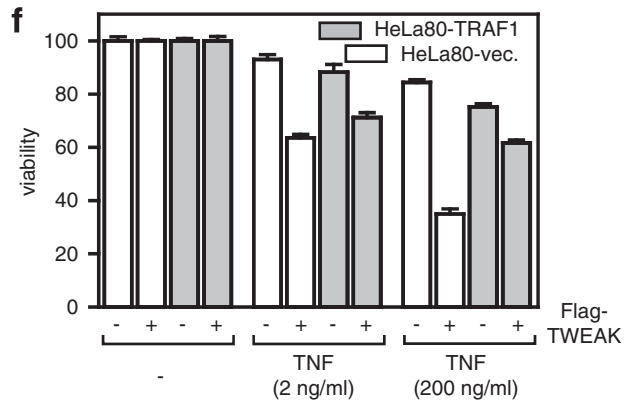

TRAF2, leading to enhanced cell death induction and reduced TNFR1-mediated $\mathrm{NF}_{\kappa} \mathrm{B}$ signaling (Figures $1 \mathrm{~b}, 2,3,8$ and reference Vince et $a l^{14}$ ). In agreement with the idea that TWEAK-induced TRAF2 depletion interferes with the recruitment of complexes of TRAF2 and cIAP1/2, TNFR1-induced ubiquitination of receptor-associated RIP1 was strongly diminished in TWEAK-stimulated cells (Figure 2e). RIP ubiquitination is a crucial event in TNFR1-induced NF $\kappa$ B signaling ${ }^{51-54}$ and is mediated by the TRAF2-interacting E3 ligases, clAP1 and 2.55,56 Although TWEAK stimulation resulted in a strong reduction of TRAF2 in the triton X-100 fraction (Figure 1b), its concentration within the TNFR1 signaling complex was less severely affected (Figure 2e). As RIP ubiquitination was nevertheless almost fully blocked, it is tempting to speculate that TRAF2 complexes containing clAP1/2 are preferentially depleted compared with TRAF2 complexes without clAP1/2. In fact, compared with TRAF2, clAP1 and clAP2 are poorly expressed and thus might fall much faster under a critical threshold. In further accordance with a receptor-proximal action of TWEAK on TNFR1 signaling, TWEAK enhanced cell death induction by TNFR1, but not by the closely related TRAIL death receptors (Figure 3 ) that converge with TNFR1 with respect to apoptosis induction at the level of FADD and caspase-8. ${ }^{1}$ Apoptosis induction by TNFR1 and TRAIL death receptors is very efficiently blocked by FADD and caspase-8-interacting FLIP proteins. Notably, the available data give evidence that enhancement of TNFR1induced cell death by TWEAK occurs upstream or parallel to the action of the FLIP proteins. First, the aforementioned fact that TRAIL-induced cell death remained unaffected by TWEAK points to a FLIP-independent target of TWEAK. Second, with the exception of Kym-1 cells, all cells investigated in our study required $\mathrm{CHX}$ sensitization to undergo robust apoptosis. Now, the sensitizing effect of $\mathrm{CHX}$ has mainly been traced back to a reduction in the expression of the short-lived anti-apoptotic FLIP proteins. ${ }^{25-28}$ TWEAK treatment failed to overcome the requirement for $\mathrm{CHX}$ sensitization, again arguing for a FLIP-independent mode of action. The idea that TNFR1-induced cell death is separately regulated by a $\mathrm{CHX}$-sensitive, FLIP-dependent mechanism and by a $\mathrm{CHX}$ insensitive, TRAF2-dependent mechanism is in good accordance with data obtained by the analysis of MEF. Hence, TRAF2-deficient as well as TRAF2/5-deficient embryonal fibroblasts still exert a strong enhancement of TNFR1induced cell death by $\mathrm{CHX}$ treatment, whereas FLIP-deficient MEFs display a strong and rapid TNF-induced apoptosis in the absence of $\mathrm{CHX}{ }^{23,57-59}$

Taken together, in a way related to TNFR2, TWEAK and its receptor Fn14 have the potential to regulate the amplitude of the proinflammatory TNFR1 response or even shift the quality 
a

Triton X100 lysates total cells

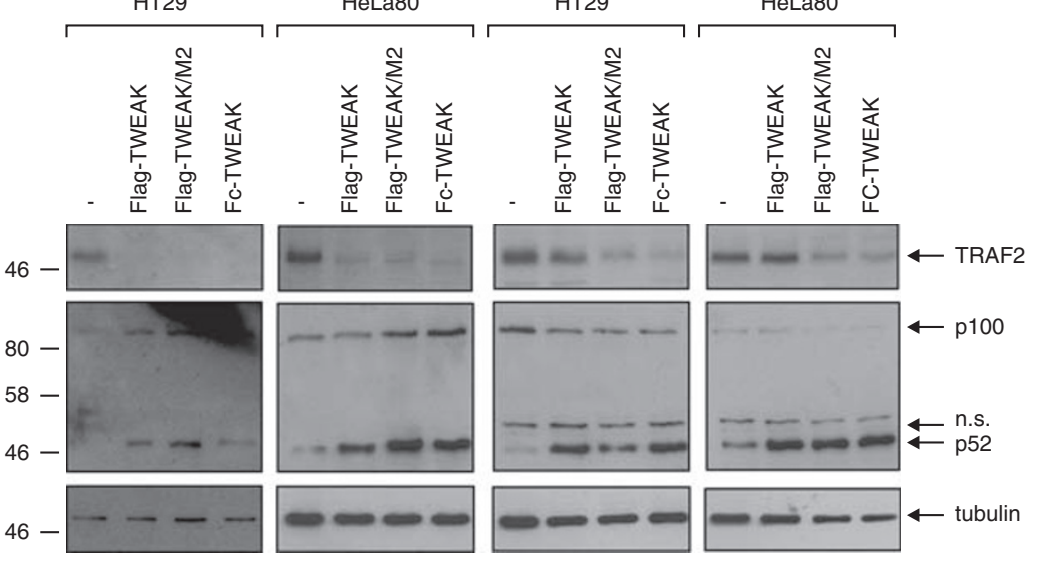

b
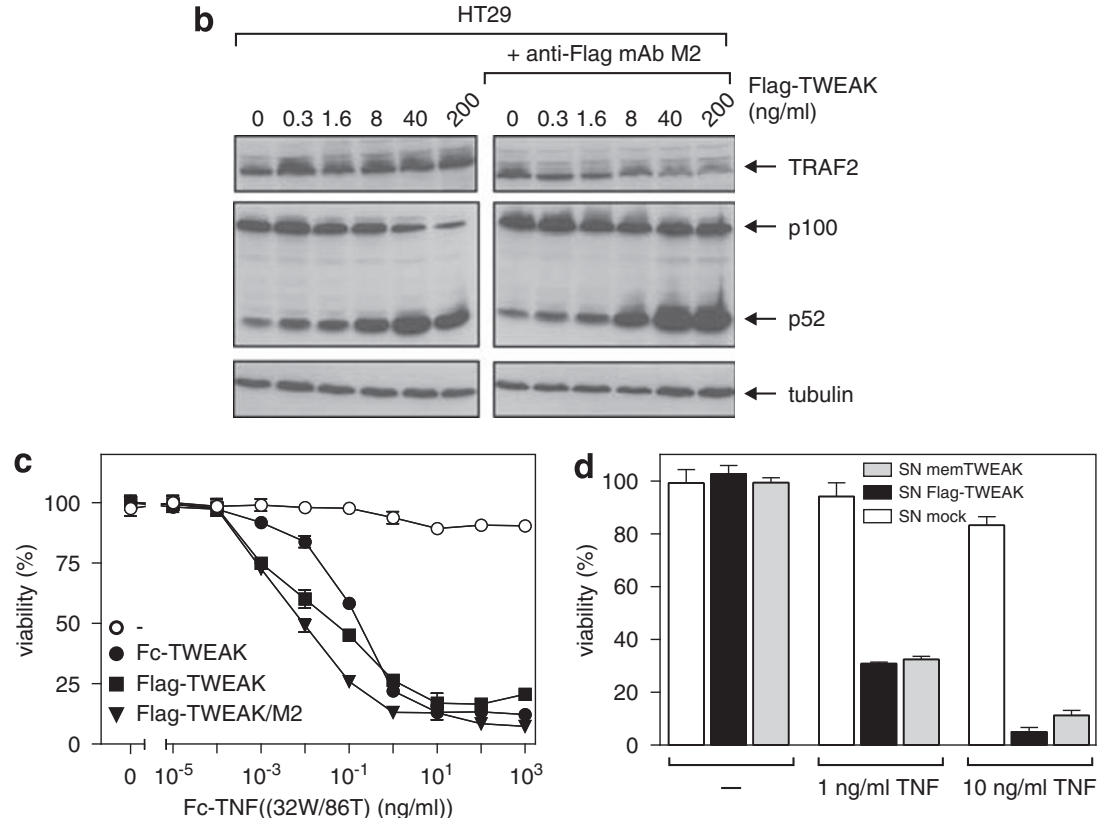

Figure 6 Oligomerized, but not trimeric soluble, TWEAK reduces the total cellular TRAF2 content. (a) HT29 and HeLa80 cells were stimulated with $200 \mathrm{ng}$ of Fc-TWEAK, anti-Flag mAb M2 $(0.5 \mu \mathrm{g} / \mathrm{ml})$, cross-linked Flag-TWEAK $(200 \mathrm{ng} / \mathrm{ml})$ or $200 \mathrm{ng} / \mathrm{ml} \mathrm{Flag-TWEAK} \mathrm{for} 18 \mathrm{~h}$. Cells were either directly boiled in Laemmli sample buffer or lysed in triton X-100 buffer. All samples were finally analyzed by western blotting with respect to TRAF2, p100 and tubulin. (b) HT29 cells were stimulated for $6 \mathrm{~h}$ with the indicated concentration of Flag-TWEAK, in the presence and absence of anti-Flag mAb M2 $(0.5 \mu \mathrm{g} / \mathrm{ml})$. Total cell lysates were then analyzed by western blotting to detect p100, p52 and tubulin was used as loading control. (c) HT29 cells were primed with $200 \mathrm{ng} / \mathrm{ml}$ of Flag-TWEAK (black squares) of anti-Flag M2 oligomerized Flag-TWEAK or Fc-TWEAK for $6 \mathrm{~h}$. Cells were then stimulated overnight in triplicates with the indicated concentrations of Fc-TNF-32W/86T, in the presence of $2.5 \mu \mathrm{g} / \mathrm{ml} \mathrm{CHX}$, and cell viability was quantified by crystal violet staining. (d) Supernatants (SN) of NCTC cells transiently transfected with an empty vector or plasmids encoding membrane-TWEAK and Flag-TWEAK, were cleared by ultracentrifugation, adjusted to a TWEAK content of $200 \mathrm{ng} / \mathrm{ml}$ and used to prime HT29 cells for $6 \mathrm{~h}$. Cells were challenged with 1 and $10 \mathrm{ng}$ of Fc-TNF-32W/86T in the presence of $\mathrm{CHX}(2.5 \mu \mathrm{g} / \mathrm{ml})$, and after an overnight incubation, cell viability was determined. The enhancing effect on the TNF-induced cell death of Flag-TWEAK and membrane TWEAK supernatants was, in all cases, highly significant (student's $T$-test $P<0.0001$ ). Molecular weight markers are indicated on the left side of the blots

of cellular TNF responses from inflammation to cell death (Figure 8). Notably, the TNFR2/FN14-related TNF receptors, CD30, CD40, OX40 and 41BB, also induce TRAF2 degradation and enhancement of TNFR1-induced apoptosis. ${ }^{32,50,60}$ Thus, TRAF2 degradation/depletion seems to be a general regulatory principle by which the quality of TNFR1 signaling can be controlled by other ligands/receptors.

We observed further that the TRAF2-interacting TRAF1 protein, which is readily induced in most cells by TNF and other inducers of $\mathrm{NF} \kappa \mathrm{B}$ activity, antagonizes TRAF2 translo- cation into the triton $\mathrm{X}$-100-insoluble fraction. Accordingly, we found in a HeLa80 transfectant with 'physiological' TRAF1 expression a reduced inhibitory effect of TWEAK on TNFR1mediated $\mathrm{NF} \kappa \mathrm{B}$ activation (Figures 5 and 8 ). Thus, the regulation of TNFR1 signaling by FN14 and other TRAF2degrading receptors could be further fine-tuned by the constitutive and inducible expression of TRAF1. Inhibition of TNFR1-induced NF $\kappa$ B activation by TWEAK becomes relevant only under pre-stimulatory conditions (Figure $5 e$ and $\mathrm{f}$ ), and TRAF 1 is typically not expressed in most cells. This opens 


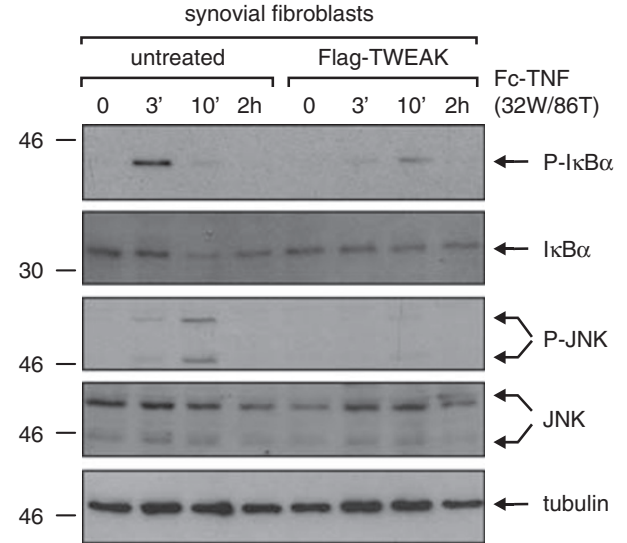

Figure 7 TWEAK inhibits TNFR1-mediated activation of NF $\kappa B$ and JNK in synovial fibroblasts. Synovial fibroblasts were primed with Flag-TWEAK $(200 \mathrm{ng} / \mathrm{ml})$ for $6 \mathrm{~h}$ or remained untreated. Cells were then challenged for the indicated time with the TNFR1-specific TNF mutant, Fc-TNF-32W/86T $(50 \mathrm{ng} / \mathrm{ml})$. Activation of the $\mathrm{NF} \kappa \mathrm{B}$ and JNK pathway was monitored by western blotting for the presence of phospho-JNK, phospho-I $\mathrm{I}_{\mathrm{B}} \alpha$ and $\mathrm{I}_{\kappa} \mathrm{B} \alpha$. Detection of total JNK and tubulin served as loading controls. Molecular weight markers are indicated to the left of the blots

the question for the 'physiological' situation(s) in which TWEAK stimulation and/or TRAF1 expression could get relevance for TNFR1 signaling. TWEAK priming definitely reflects the fact that TWEAK can induce TNF in a cell-typespecific manner. ${ }^{14,29}$ Thus, TWEAK-induced TNF will act in an autocrine manner on the 'TWEAK'-primed, TNF-producing cell itself, and, in addition, in a paracrine mode on neighboring TWEAK-stimulated cells. TRAF1 is admittedly not expressed in non-stimulated cells, but is typically induced by TNF. Hence, soon after TNFR1 stimulation, TRAF1 has no relevance for TNFR1 signaling and/or the TRAF2-mediated TWEAK-TNFR1 cross talk, but with time, TNFR1-induced TRAF1 will interact with the remaining or newly synthesized TRAF2 and thereby modulate the TWEAK-TNFR1 cross talk. Thus, TRAF1 might become especially relevant in situations of durable/long lasting TWEAK/TNF exposition.

Although TNFR1-induced apoptosis has been studied intensively, the overwhelming relevance of TNF and therapeutic TNF blockade in vivo is related to its proinflammatory functions. The latter emanates mainly from the strong capability of TNFR1 to activate the classical NF $\kappa$ B pathway. Notably, TWEAK can also activate the classical $\mathrm{NF} \kappa \mathrm{B}$ pathway and there is indeed evidence that it acts in concert with TNF in chronic proinflammatory autoimmune diseases. ${ }^{61-63}$ The anti-inflammatory, inhibitory effect of soluble TWEAK trimers on TNF-induced $\mathrm{NF}_{\kappa} \mathrm{B}$ activity reported here is therefore unexpected and, at first glance, contradictory to its earlier mentioned proinflammatory role in vivo. However, the fact that the soluble and transmembrane forms of some members of the TNF ligand family differ in their bioactivity might resolve this conflict. ${ }^{40}$ We observed that trimeric soluble TWEAK and oligomerized TWEAK have a different capability to degrade TRAF2 (Figure 6). In addition, we observed in some cell lines a strong enhancement of TWEAK-induced classical NF $\kappa$ B signaling upon oligomerization of Flag-TWEAK (data not shown, manuscript in preparation). For other TNF ligands that are inactive/poorly active as soluble trimers, it has been found that oligomerized soluble trimers mimic the activity of the corresponding membranebound molecule. ${ }^{40}$ It is therefore tempting to speculate that the aforementioned difference in TRAF2 degradation by FlagTWEAK and Fc-TWEAK (Figure 6) reflects different activities of transmembrane TWEAK and soluble TWEAK. Transmembrane TWEAK is mainly expressed by activated monocytes and is readily converted by furin into soluble molecules. The inflammatory effect of TWEAK might therefore differ in cells having contact with monocytes and distant cells in a monocytefree environment.

\section{Materials and Methods}

Cell lines, reagents and antibodies. HeLa80, HT29, KB, CoLo357, HT1080, Kym-1, HUT78 and the endothelial-like EAhy926 cell line, which was obtained by fusion of human umbilical vein endothelial cells and the carcinoma cell line, A549, ${ }^{64}$ were maintained in RPMl1640 medium (PAA, Pasching, Germany) containing $10 \%$ heat-inactivated fetal calf serum (PAA). HaCaT, the retroviralpackaging cell line, the Phoenix-gibbon ape leukemia virus (GALV) and synovial fibroblasts were grown in Dulbecco's modified Eagle's medium supplemented with $10 \%$ fetal calf serum. ${ }^{65}$ The HeLa population stably overexpressing TNFR2 (HeLa80) has been described previously. ${ }^{44}$ Flag-TWEAK, FC-TWEAK and the TNFR1-specific mutant of TNF (FC-TNF(32W/86T) ${ }^{66}$ were produced in HEK293 cells. TNF was a kind gift from Daniela Männel (University of Regensburg, Regensburg, Germany). Cycloheximide (CHX) and protein $\mathrm{G}$ agarose beads were purchased from Sigma (Deisenhofen, Germany). Z-VAD-fmk was obtained from Bachem (Heidelberg, Germany) and Killer-TRAIL from Axxora (Lörrach, Germany). Antibodies specific for caspase-9, JNK, phospho-JNK, p4/42 and phospho-IB $\alpha$ were purchased from Cell Signaling (Beverly, MA, USA). I $\kappa \mathrm{B} \alpha$, TNFR1-, TRAF1-, TRAF2-specific antibodies were obtained from Santa Cruz (Santa Cruz, CA, USA), anti-RIP and-caspase-2 and anti-IKK $\alpha$ were from BD Biosciences Pharmingen (Heidelberg, Germany), anti- $\beta$-actin was from Sigma, anti-tubulin was from Dunn Labortechnik (Ansbach, Germany) and anti-NF $\kappa$ B p52 was from Millipore (Schwalbach, Germany).

Isolation and culture of synovial fibroblasts. Synovial tissues were obtained from patients undergoing synovectomy or joint replacement surgery after obtaining written consent. After surgery, synovial tissue was chopped into small fragments, washed thrice with cold phosphate-buffered saline and digested with Dispase 2 (Sigma) at $37^{\circ} \mathrm{C}$ for $30 \mathrm{~min}$ under gentle agitation. The obtained cell suspension was seeded into tissue culture flasks. Adherent fibroblasts from passages 4-10 were used for experiments.

Retroviral infection. A TRAF1-encoding CDNA fragment was cloned into the retroviral vector, pLZNGFR-PKG (kind gift of Dr. Max Topp, University of Würzburg, Germany), placing TRAF1 under the control of the PKG promoter. Upstream of the mouse PKG promoter, a truncated version of the human low-affinity NGFR is expressed by the $5^{\prime}$-long terminal repeat of the vector. The retroviral TRAF1 construct was transfected into the Phoenix-GALV-packing cell line using Lipofectamine (Invitrogen, Karlsruhe, Germany). After 7-10 days, virus particlecontaining supernatants were harvested from puromycin-resistant cells. After filtration $(0.4 \mu \mathrm{m})$, the supernatants were added to HeLa80 cells and centrifuged for $3 \mathrm{~h}$ at $21^{\circ} \mathrm{C}$ in the presence of $1 \mu \mathrm{g} / \mathrm{ml}$ polybrene. After an additional 7 days, the cells were analyzed for NGFR expression by FACS and thereafter immunoselected with NGFR beads (Milteny Biotech, Bergisch-Gladbach, Germany). Finally, individual clones were obtained by limited dilution and screened for 'physiological' TRAF1 expression levels by western blotting.

Cell death assay. Cells $\left(17 \times 10^{3}\right.$ per well) were seeded in 96 -well plates. The next day, the cells were treated for $6 \mathrm{~h}$ with Flag-TWEAK or medium, and finally challenged in triplicates with the indicated concentrations of Fc-TNF(32W/86T) or Killer-TRAIL in the presence or absence of $\mathrm{CHX}(2.5 \mu \mathrm{g})$. Cell viability was determined after $16 \mathrm{~h}$ by crystal violet staining.

Determination of IL8 production. Cells $\left(20 \times 10^{3}\right)$ were seeded in triplicates in 96 -well tissue culture plates and cultured overnight. The following day, the cells were stimulated with $200 \mathrm{ng} / \mathrm{ml}$ Flag-TWEAK or medium overnight. The 
a
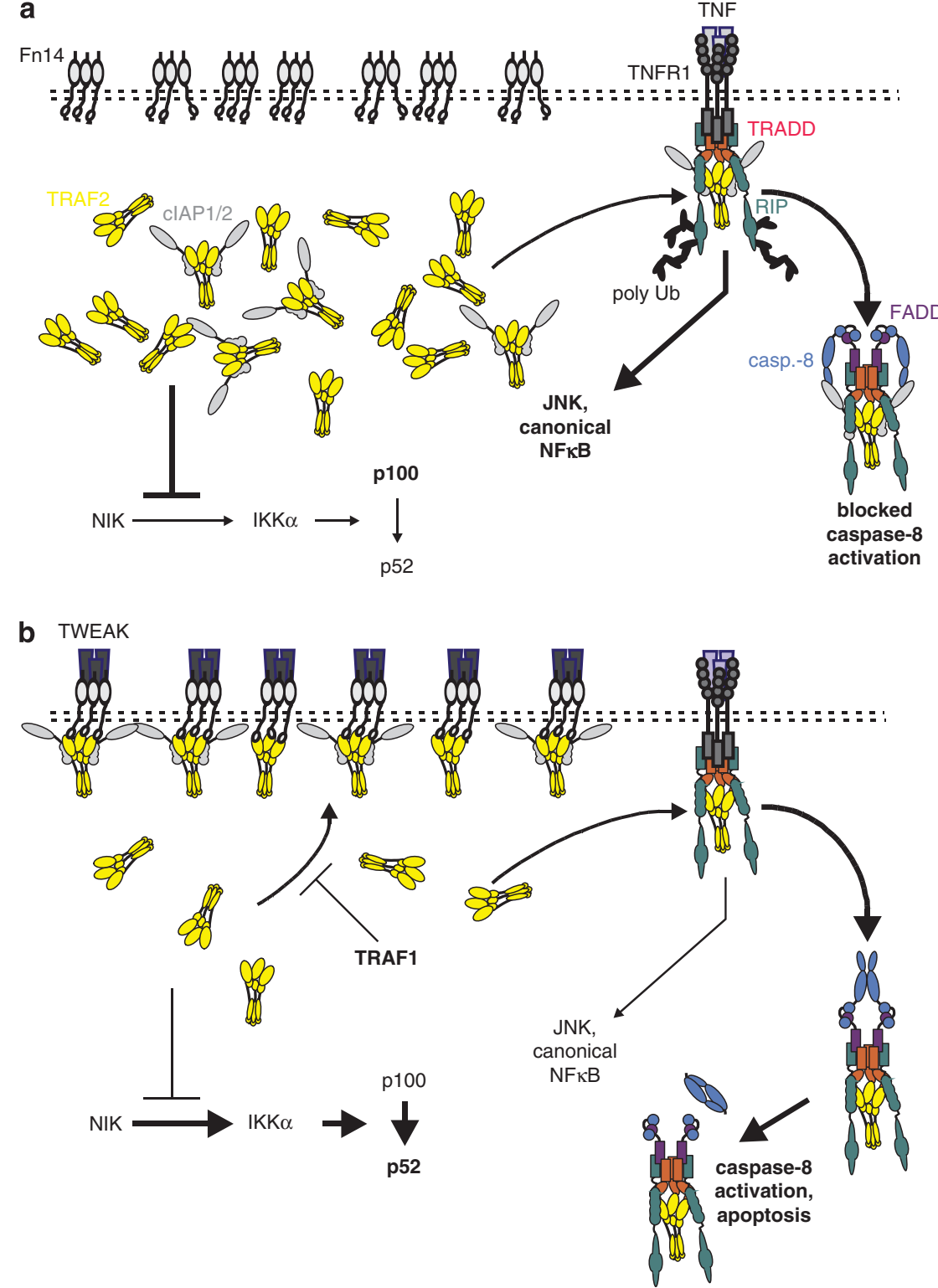

Figure 8 Model of TWEAK-regulated TNFR1 signaling. (a) In the absence of TWEAK pre-stimulation, TNFR1 activation by soluble TNF results in the recruitment of TRADD, RIP, TRAF2 and TRAF2/CIAP complexes, leading to ubiquitination of RIP and activation of JNK and the canonical NF $\kappa$ B-signaling pathway. Owing to the low cell surface expression of TNFR1 ( $<1000-2500$ molecules per cell), recruitment of TRAF2 and clAPs has no major effect on the 'freely' available cytosolic pool of these molecules, and thus does not result in activation of the alternative $\mathrm{NF}_{\kappa} B$ pathway. Upon internalization, there is a secondary formation of a TNFR1-induced TRADD, RIP, FADD, caspase-8, TRAF2 and cIAP1/2-containing complex, in which caspase-8 activation is blocked by cIAP1/2, yet is a poorly understood mechanism. ${ }^{68}$ (b) In TWEAKprimed cells, the cytosolic pool of TRAF2 and TRAF2 complexes with other proteins, especially cIAPs, has been depleted because of the high expression of the TWEAK receptor, Fn14. As a consequence, NIK is relieved from the inhibitory action of TRAF2 and is now able to stimulate the alternative $\mathrm{NF}_{\kappa} \mathrm{B}$ pathway. ${ }^{22,69,70} \mathrm{Owing}$ to the lack of TRAF2 and especially TRAF2/CIAP complexes, $N F F_{\kappa} B$ and JNK inducing RIP ubiquitination in the TNFR1 signaling complex is disturbed. ${ }^{50-56}$ Furthermore, owing to the lack of CIAP1/2, caspase-8 processing is now possible in the secondary complex and results in apoptosis. ${ }^{42}$ The latter is further dependent on the additional absence of FLIP or other anti-apoptotic molecules acting downstream of the secondary complex. Please note that TRAF1 antagonizes the inhibitory effect of TWEAK on proinflammatory TNFR1 signaling by attenuating TWEAK-induced TRAF2 depletion

next day, the medium was changed and cells were incubated for 6 hours with the indicated concentrations of TNF. Finally, supernatants were collected and IL8 was quantified by enzyme-linked immunosorbent assay (BD Biosciences Pharmingen).

Western blotting. For the detection of phosphorylated proteins, cells were harvested into ice-cold phosphate-buffered saline, collected by centrifugation and then directly lyzed in $4 x$ modified Laemmli sample buffer ( $8 \%$ SDS, $80 \mathrm{mM}$ dithiothreitol, 40\% glycine, $240 \mathrm{mM}$ Tris, $\mathrm{pH} 6.8,0.004 \%$ bromphenol blue) supplemented with phosphatase inhibitor cocktails I and II (Sigma). After sonification (10s), protein samples were boiled for $5 \mathrm{~min}$ at $96^{\circ} \mathrm{C}$, separated by sodium dodecyl sulfate-polyacrylamide gel electrophoresis (SDS-PAGE) and transferred to nitrocellulose membranes. After blocking of nonspecific binding sites by incubation in Tris-buffered saline containing $0.1 \%$ Tween 20 and $5 \%$ dry milk, western blot analyses were carried out with primary antibodies of indicated specificity, horseradish peroxidase-conjugated secondary antibodies (Dako, Hamburg, Germany) and the ECL western blotting detection reagents and analysis system (Amersham Biosciences, Freiburg, Germany). For preparation of triton X-100 lysates, cells were washed with ice-cold phosphate-buffered saline and 
lysed with lysis buffer $(30 \mathrm{mM}$ Tris- $\mathrm{HCl}, \mathrm{pH} 7.5,1 \%$ triton $\mathrm{X}-100,10 \%$ glycerol, $120 \mathrm{mM} \mathrm{NaCl}$ ) supplemented with complete protease inhibitor cocktail (Roche Diagnostics $\mathrm{GmbH}$, Mannheim, Germany) for $20 \mathrm{~min}$ on ice. Thereafter, the lysates were centrifuged twice $(5 \mathrm{~min}, 5000 \times \mathrm{g}$; $20 \mathrm{~min}, 14000 \times \mathrm{g})$ before the $4 \times$ Laemmli sample buffer was added and samples were heated for 5 min at $96^{\circ} \mathrm{C}$.

Cytoplasmic and nuclear fractionation. Cytoplasmic and nuclear extracts were prepared using the Nuclear Extraction Kit (Thermo Scientific, Schwerte, Germany) according to the manufacturer's protocol. The quality of cytoplasmic-nuclear fractionation was controlled by immunoblotting using antitubulin for the cytoplasmic extract and anti-lamin-B for the nuclear extract.

Isolation of detergent-insoluble membrane fractions. $3 \times 10^{7}$ cells were harvested, suspended in $200 \mu \mathrm{l}$ serum-free RPMI medium and lyzed in $200 \mu \mathrm{l}$ ice-cold triton X-100 lysis buffer ( $0.8 \%$ triton X-100 in TNE (25 mM Tris, pH 7.5, $150 \mathrm{mM} \mathrm{NaCl}, 5 \mathrm{mM}$ EDTA, $1 \mathrm{mM}$ Pefabloc, $5 \mathrm{mM}$ iodoacetamide; $1 \mathrm{mM} \mathrm{Na}_{3} \mathrm{VO}_{4}$, $1 \mathrm{mM} \mathrm{NaF})$ ). The lysates were loaded on sucrose gradients, as described elsewhere. ${ }^{67}$ The samples were centrifuged at $50000 \mathrm{~g}$. in a Beckmann SW60 rotor (Beckmann Coulter, Krefeld, Germany) for $22 \mathrm{~h}$ at $4^{\circ} \mathrm{C}$ Four fractions were derived from each sample and analyzed by western blotting. The upper fraction was identified as a detergent-insoluble raft membrane fraction by control blots using flotillin as marker.

Flow cytometry. Cells were incubated for $30 \mathrm{~min}$ at $4^{\circ} \mathrm{C}$ with a PE-conjugated Fn14-specific antibody, ITEM-4 (NatuTec, Frankfurt, Germany), anti-human NGFR (Milteny) or an appropriate isotype control (R\&D Systems, Wiesbaden, Germany). Analyses were carried out using FACSCalibur (BD Biosciences) according to standard procedures.

EGFP reporter gene assay. Cells were seeded in $6 \mathrm{~cm}$ cell culture dishes and were transfected the next day with $8 \mu \mathrm{g}$ DNA of the pNF $\kappa$ B-d2EGFP reporter gene plasmid (Clonetech, Saint-Germain-en-Laye, France) using Lipofectamine 2000 (Invitrogen). After an additional day, the cells were harvested, split in triplicates and stimulated as indicated. The following day, the cells were harvested and $\mathrm{NF} \kappa \mathrm{B}$ activation was analyzed by FACS.

Coimmunoprecipitation. Immunoprecipitation of TNFR1 was performed with a TNFR1-specific immunoglobulin Fc fusion protein of TNF (Fc-TNF(32W/ $86 \mathrm{~T})$ ), using one confluent $175-\mathrm{cm}^{2}$ flask of cells per condition. If indicated, the cells were pre-stimulated with $200 \mathrm{ng} / \mathrm{ml}$ Flag-TWEAK in $5 \mathrm{ml}$ medium for $6 \mathrm{~h}$ at $37^{\circ} \mathrm{C}$. Subsequently, the medium was removed and $5 \mathrm{ml}$ of medium containing $\mathrm{Fc}$ $\operatorname{TNF}(32 \mathrm{~W} / 86 \mathrm{~T})$ at a concentration of $400 \mathrm{ng} / \mathrm{ml}$ was added. After incubation at $37^{\circ} \mathrm{C}$ for 3 or $10 \mathrm{~min}$, the cells were washed in ice-cold PBS thrice and lysed with $1.5 \mathrm{ml}$ lysis buffer ( $30 \mathrm{mM}$ Tris- $\mathrm{HCl}, \mathrm{pH} 7.5,1 \%$ triton $\mathrm{X}-100,10 \%$ glycerol, $120 \mathrm{mM} \mathrm{NaCl})$ supplemented with complete protease inhibitor cocktail (Roche Diagnostics $\mathrm{GmbH}$ ) for $20 \mathrm{~min}$ on ice. The lysates were centrifuged thrice $(5 \mathrm{~min}, 5000 \mathrm{~g} ; 2 \times 20 \mathrm{~min}$, $14000 \mathrm{~g}$ ) and TNFR1 complexes were precipitated from the cleared lysate with protein $\mathrm{G}$ agarose ( $40 \mu \mathrm{l}$ of a $50 \%$ slurry) at $4{ }^{\circ} \mathrm{C}$ overnight. As a negative control, lysates from un-stimulated cells were supplemented with $50 \mathrm{ng}$ of Fc-TNF $(32 \mathrm{~W} / 86 \mathrm{~T})$ and $50 \mathrm{ng}$ Flag-TWEAK before adding protein $\mathrm{G}$ beads. The precipitates were washed five times in ice-cold lysis buffer and bound proteins were eluted by incubation at $75^{\circ} \mathrm{C}$ for $10 \mathrm{~min}$ in $4 \times$ Laemmli sample buffer.

Acknowledgements. This work was supported by Deutsche Forschungsgemeinschaft (DFG Wa 1025/18-1; DFG He 5275/2-1 and Sonderforschungsbereich 487 project B7) and IZKF Würzburg (project A49).

1. Wajant H, Pfizenmaier K, Scheurich P. Tumor necrosis factor signaling. Cell Death Differ 2003; 10: 45-65.

2. Bodmer JL, Schneider P, Tschopp J. The molecular architecture of the TNF superfamily. Trends Biochem Sci 2002; 27: 19-26.

3. Chicheportiche Y, Bourdon PR, Xu H, Hsu YM, Scott H, Hession C et al. TWEAK, a new secreted ligand in the tumor necrosis factor family that weakly induces apoptosis. J Biol Chem 1997; 272: 32401-32410.

4. Brown SA, Richards CM, Hanscom HN, Feng SL, Winkles JA. The Fn14 cytoplasmic tail binds tumour-necrosis-factor-receptor-associated factors $1,2,3$ and 5 and mediates nuclear factor-kappaB activation. Biochem J 2003; 371: 395-403.
5. Saitoh T, Nakayama M, Nakano H, Yagita H, Yamamoto N, Yamaoka S. TWEAK induces NF-kappaB2 p100 processing and long lasting NF-kappaB activation. J Biol Chem 2003; 278: 36005-36012.

6. Polek TC, Talpaz M, Darnay BG, Spivak-Kroizman T. TWEAK mediates signal transduction and differentiation of RAW264.7 cells in the absence of Fn14/TweakR. Evidence for a second TWEAK receptor. J Biol Chem 2003; 278: 32317-32323.

7. Ando T, Ichikawa J, Wako M, Hatsushika K, Watanabe $Y$, Sakuma M et al. TWEAK/Fn14 interaction regulates RANTES production, BMP-2-induced differentiation, and RANKL expression in mouse osteoblastic MC3T3-E1 cells. Arthritis Res Ther 2006; 8: R146.

8. Burkly LC, Michaelson JS, Hahm K, Jakubowski A, Zheng TS. TWEAKing tissue remodeling by a multifunctional cytokine: role of TWEAK/Fn14 pathway in health and disease. Cytokine 2007; 40: 1-16.

9. Marsters SA, Sheridan JP, Pitti RM, Brush J, Goddard A, Ashkenazi A. Identification of a ligand for the death-domain-containing receptor Apo3. Curr Biol 1998; 8: 525-528.

10. Kaptein A, Jansen M, Dilaver G, Kitson J, Dash L, Wang E et al. Studies on the interaction between TWEAK and the death receptor WSL-1/TRAMP (DR3). FEBS Lett 2000; 485: $135-141$.

11. Meighan-Mantha RL, Hsu DK, Guo Y, Brown SA, Feng SL, Peifley KA et al. The mitogeninducible Fn14 gene encodes a type I transmembrane protein that modulates fibroblast adhesion and migration. J Biol Chem 1999; 274: 33166-33176.

12. Wiley SR, Cassiano L, Lofton T, Davis-Smith T, Winkles JA, Lindner V et al. A novel TNF receptor family member binds TWEAK and is implicated in angiogenesis. Immunity 2001; 15: 837-846.

13. Han S, Yoon K, Lee K, Kim K, Jang H, Lee NK et al. TNF-related weak inducer of apoptosis receptor, a TNF receptor superfamily member, activates NF-kappa B through TNF receptor-associated factors. Biochem Biophys Res Commun 2003; 305: 789-796.

14. Vince JE, Chau D, Callus B, Wong WW, Hawkins CJ, Schneider P et al. TWEAK-FN14 signaling induces lysosomal degradation of a cIAP1-TRAF2 complex to sensitize tumor cells to TNFalpha. J Cell Biol 2008; 182: 171-184.

15. Feng SL, Guo Y, Factor VM, Thorgeirsson SS, Bell DW, Testa JR et al. The Fn14 immediate-early response gene is induced during liver regeneration and highly expressed in both human and murine hepatocellular carcinomas. Am J Pathol 2000; 156: 1253-1261.

16. Jakubowski A, Ambrose C, Parr M, Lincecum JM, Wang MZ, Zheng TS et al. TWEAK induces liver progenitor cell proliferation. J Clin Invest 2005; 115: 2330-2340.

17. Desplat-Jego S, Creidy R, Varriale S, Allaire N, Luo Y, Bernard D et al. Anti-TWEAK monoclonal antibodies reduce immune cell infiltration in the central nervous system and severity of experimental autoimmune encephalomyelitis. Clin Immunol 2005; 117: 15-23.

18. Girgenrath M, Weng S, Kostek CA, Browning B, Wang M, Brown SA et al. TWEAK, via its receptor $\mathrm{Fn} 14$, is a novel regulator of mesenchymal progenitor cells and skeletal muscle regeneration. EMBO J 2006; 25: 5826-5839.

19. Vince JE, Silke J. TWEAK shall inherit the earth. Cell Death Differ 2006; 13: 1842-1844.

20. Dogra C, Changotra H, Mohan S, Kumar A. Tumor necrosis factor-like weak inducer of apoptosis inhibits skeletal myogenesis through sustained activation of nuclear factorkappaB and degradation of MyoD protein. J Biol Chem 2006; 281: 10327-10336.

21. Perper SJ, Browning B, Burkly LC, Weng S, Gao C, Giza $\mathrm{K}$ et al. TWEAK is a novel arthritogenic mediator. J Immunol 2006; 177: 2610-2620.

22. Gardam S, Sierro F, Basten A, Mackay F, Brink R. TRAF2 and TRAF3 signal adapters act cooperatively to control the maturation and survival signals delivered to $B$ cells by the BAFF receptor. Immunity 2008; 28: 391-401.

23. Tada K, Okazaki T, Sakon S, Kobarai T, Kurosawa K, Yamaoka S et al. Critical roles of TRAF2 and TRAF5 in tumor necrosis factor-induced NF-kappa $B$ activation and protection from cell death. J Biol Chem 2001; 276: 36530-36534.

24. Yeh WC, Shahinian A, Speiser D, Kraunus J, Billia F, Wakeham A et al. Early lethality, functional NF-kappaB activation, and increased sensitivity to TNF-induced cell death in TRAF2-deficient mice. Immunity 1997; 7: 715-725.

25. Leverkus M, Neumann M, Mengling T, Rauch CT, Brocker EB, Krammer PH et al. Regulation of tumor necrosis factor-related apoptosis-inducing ligand sensitivity in primary and transformed human keratinocytes. Cancer Res 2000; 60: 553-559.

26. Wajant H, Haas E, Schwenzer R, Muhlenbeck F, Kreuz S, Schubert G et al. Inhibition of death receptor-mediated gene induction by a cycloheximide-sensitive factor occurs at the level of or upstream of Fas-associated death domain protein (FADD). J Biol Chem 2000; 275: 24357-24366.

27. Fulda S, Meyer E, Debatin KM. Metabolic inhibitors sensitize for CD95 (APO-1/Fas)induced apoptosis by down-regulating Fas-associated death domain-like interleukin 1 converting enzyme inhibitory protein expression. Cancer Res 2000; 60: 3947-3956.

28. Siegmund D, Hadwiger P, Pfizenmaier K, Vornlocher HP, Wajant H. Selective inhibition of FLICE-like inhibitory protein expression with small interfering RNA oligonucleotides is sufficient to sensitize tumor cells for TRAIL-induced apoptosis. Mol Med 2002; 8: 725-732.

29. Schneider $P$, Schwenzer R, Haas E, Muhlenbeck F, Schubert G, Scheurich P et al. TWEAK can induce cell death via endogenous TNF and TNF receptor 1. Eur J Immunol 1999; 29: 1785-1792.

30. Nakayama M, Ishidoh $\mathrm{K}$, Kayagaki $\mathrm{N}$, Kojima $\mathrm{Y}$, Yamaguchi $\mathrm{N}$, Nakano $\mathrm{H}$ et al. Multiple pathways of TWEAK-induced cell death. J Immunol 2002; 168: 734-743.

31. Wilson CA, Browning JL. Death of HT29 adenocarcinoma cells induced by TNF family receptor activation is caspase-independent and displays features of both apoptosis and necrosis. Cell Death Differ 2002; 9: 1321-1333. 
32. Fotin-Mleczek M, Henkler F, Samel D, Reichwein M, Hausser A, Parmryd I et al. Apoptotic crosstalk of TNF receptors: TNF-R2-induces depletion of TRAF2 and IAP proteins and accelerates TNF-R1-dependent activation of caspase-8. J Cell Sci 2002; 115: 2757-2770.

33. Degterev A, Hitomi J, Germscheid M, Ch'en IL, Korkina O, Teng X et al. Identification of RIP1 kinase as a specific cellular target of necrostatins. Nat Chem Biol 2008; 4: 313-321.

34. Fotin-Mleczek M, Henkler F, Hausser A, Glauner H, Samel D, Graness A et al. Tumor necrosis factor receptor-associated factor (TRAF) 1 regulates CD40-induced TRAF2 mediated NF-kappaB activation. J Biol Chem 2004; 279: 677-685.

35. Hsu H, Shu HB, Pan MG, Goeddel DV. TRADD-TRAF2 and TRADD-FADD interactions define two distinct TNF receptor 1 signal transduction pathways. Cell 1996; 84: 299-308.

36. Schwenzer R, Siemienski K, Liptay S, Schubert G, Peters N, Scheurich P et al. The human tumor necrosis factor (TNF) receptor-associated factor 1 gene (TRAF1) is up-regulated by cytokines of the TNF ligand family and modulates TNF-induced activation of NF-kappaB and c-Jun N-terminal kinase. J Biol Chem 1999; 274: 19368-19374.

37. Carpentier I, Beyaert R. TRAF1 is a TNF inducible regulator of NF-kappaB activation. FEBS Lett 1999; 460: 246-250.

38. Dunn IF, Sannikova TY, Geha RS, Tsitsikov EN. Identification and characterization of two CD40-inducible enhancers in the mouse TRAF1 gene locus. Mol Immunol2000; 37: 961-973.

39. Henkler F, Baumann B, Fotin-Mleczek M, Weingartner M, Schwenzer R, Peters N et al. Caspase-mediated cleavage converts the tumor necrosis factor (TNF) receptor-associated factor (TRAF)- 1 from a selective modulator of TNF receptor signaling to a general inhibitor of NF-kappaB activation. J Biol Chem 2003; 278: 29216-29230.

40. Wajant $\mathrm{H}$, Gerspach J, Pfizenmaier K. Tumor therapeutics by design: targeting and activation of death receptors. Cytokine Growth Factor Rev 2005; 16: 55-76.

41. Shu HB, Takeuchi M, Goeddel DV. The tumor necrosis factor receptor 2 signal transducers TRAF2 and C-IAP1 are components of the tumor necrosis factor receptor 1 signaling complex. Proc Natl Acad Sci USA 1996; 93: 13973-13978.

42. Wang CY, Mayo MW, Korneluk RG, Goeddel DV, Baldwin Jr AS. NF-kappaB antiapoptosis: induction of TRAF1 and TRAF2 and C-IAP1 and C-IAP2 to suppress caspase-8 activation. Science 1998; 281: 1680-1683.

43. Weiss T, Grell M, Siemienski K, Muhlenbeck F, Durkop H, Pfizenmaier K et al. TNFR80 dependent enhancement of TNFR60-induced cell death is mediated by TNFR-associated factor 2 and is specific for TNFR60. J Immunol 1998; 161: 3136-3142.

44. Weiss T, Grell M, Hessabi B, Bourteele S, Muller G, Scheurich P et al. Enhancement of TNF receptor p60-mediated cytotoxicity by TNF receptor p80: requirement of the TNF receptor-associated factor-2 binding site. J Immunol 1997; 158: 2398-2404.

45. Habelhah H, Takahashi S, Cho SG, Kadoya T, Watanabe T, Ronai Z. Ubiquitination and translocation of TRAF2 is required for activation of JNK but not of p38 or NF-kappaB. EMBO J 2004; 23: 322-332.

46. Wu CJ, Conze DB, Li X, Ying SX, Hanover JA, Ashwell JD. TNF-alpha induced C-IAP1/ TRAF2 complex translocation to a Ubc6-containing compartment and TRAF2 ubiquitination. EMBO J 2005; 24: 1886-1898.

47. Zhao Y, Conze DB, Hanover JA, Ashwell JD. Tumor necrosis factor receptor 2 signaling induces selective C-IAP1-dependent ASK1 ubiquitination and terminates mitogen-activated protein kinase signaling. J Biol Chem 2007; 282: 7777-7782.

48. Li X, Yang Y, Ashwell JD. TNF-RII and c-IAP1 mediate ubiquitination and degradation of TRAF2. Nature 2002; 416: 345-347.

49. Chan FK, Lenardo MJ. A crucial role for p80 TNF-R2 in amplifying p60 TNF-R1 apoptosis signals in T lymphocytes. Eur J Immunol 2000; 30: 652-660.

50. Duckett CS, Thompson CB. CD30-dependent degradation of TRAF2: implications for negative regulation of TRAF signaling and the control of cell survival. Genes Dev 1997; 11: 2810-2821.

51. Wertz IE, O'Rourke KM, Zhou H, Eby M, Aravind L, Seshagiri S et al. De-ubiquitination and ubiquitin ligase domains of A20 downregulate NF-kappaB signalling. Nature 2004; 430 : 694-699.
52. Li H, Kobayashi M, Blonska M, You $Y$, Lin X. Ubiquitination of RIP is required for tumor necrosis factor alpha-induced NF-kappaB activation. J Biol Chem 2006; 281: 13636-13643.

53. Ea CK, Deng L, Xia ZP, Pineda G, Chen ZJ. Activation of IKK by TNFalpha requires site-specific ubiquitination of RIP1 and polyubiquitin binding by NEMO. Mol Cell 2006; 22 245-257.

54. Wu CJ, Conze DB, Li T, Srinivasula SM, Ashwell JD. Sensing of Lys 63-linked polyubiquitination by NEMO is a key event in NF-kappaB activation. Nat Cell Biol 2006; 8: 398-406.

55. Bertrand MJ, Milutinovic S, Dickson KM, Ho WC, Boudreault A, Durkin J et al. clAP1 and cIAP2 facilitate cancer cell survival by functioning as E3 ligases that promote RIP1 ubiquitination. Mol Cell 2008; 30: 689-700.

56. Varfolomeev E, Goncharov T, Fedorova AV, Dynek JN, Zobel K, Deshayes K et al. c-IAP1 and C-IAP2 are critical mediators of tumor necrosis factor alpha (TNFalpha)-induced NFkappaB activation. J Biol Chem 2008; 283: 24295-24299.

57. Yoon K, Jung EJ, Lee SR, Kim J, Choi Y, Lee SY. TRAF6 deficiency promotes TNF-induced cell death through inactivation of GSK3beta. Cell Death Differ 2008; 15: 730-738.

58. Blackwell K, Zhang L, Thomas GS, Sun S, Nakano H, Habelhah H. TRAF2 phosphorylation modulates tumor necrosis factor alpha-induced gene expression and cell resistance to apoptosis. Mol Cell Biol 2009; 29: 303-314.

59. Nakajima A, Komazawa-Sakon S, Takekawa M, Sasazuki T, Yeh WC, Yagita H et al. An antiapoptotic protein, C-FLIPL, directly binds to MKK7 and inhibits the JNK pathway. EMBO J 2006; 25: 5549-5559.

60. Arch RH, Gedrich RW, Thompson CB. Translocation of TRAF proteins regulates apoptotic threshold of cells. Biochem Biophys Res Commun 2000; 272: 936-945.

61. Winkles JA. The TWEAK-Fn14 cytokine-receptor axis: discovery, biology and therapeutic targeting. Nat Rev Drug Discov 2008; 7: 411-425.

62. Zheng TS, Burkly LC. No end in site: TWEAK/Fn14 activation and autoimmunity associated- end-organ pathologies. J Leukoc Biol 2008; 84: 338-347.

63. Yepes M. TWEAK and the central nervous system. Mol Neurobiol 2007; 35: 255-265.

64. Edgell CJ, McDonald CC, Graham JB. Permanent cell line expressing human factor VIII-related antigen established by hybridization. Proc Natl Acad Sci USA 1983; 80: 3734-3737.

65. Horn PA, Topp MS, Morris JC, Riddell SR, Kiem HP. Highly efficient gene transfer into baboon marrow repopulating cells using GALV-pseudotype oncoretroviral vectors produced by human packaging cells. Blood 2002; 100: 3960-3967.

66. Loetscher $\mathrm{H}$, Stueber D, Banner D, Mackay F, Lesslauer W. Human tumor necrosis factor alpha (TNF alpha) mutants with exclusive specificity for the $55-$ or $75-\mathrm{kDa}$ TNF receptors. J Biol Chem 1993; 268: 26350-26357.

67. Henkler F, Behrle E, Dennehy KM, Wicovsky A, Peters N, Warnke $C$ et al. The extracellular domains of FasL and Fas are sufficient for the formation of supramolecular FasL-Fas clusters of high stability. J Cell Biol 2005; 168: 1087-1098.

68. Schutze S, Tchikov V, Schneider-Brachert W. Regulation of TNFR1 and CD95 signalling by receptor compartmentalization. Nat Rev Mol Cell Biol 2008; 9: 655-662.

69. Zarnegar BJ, Wang Y, Mahoney DJ, Dempsey PW, Cheung HH, He J et al. Noncanonical NF-kappaB activation requires coordinated assembly of a regulatory complex of the adaptors cIAP1, cIAP2, TRAF2 and TRAF3 and the kinase NIK. Nat Immunol 2008; 9 : 1371-1378.

70. Vallabhapurapu S, Matsuzawa A, Zhang W, Tseng PH, Keats JJ, Wang $\mathrm{H}$ et al. Nonredundant and complementary functions of TRAF2 and TRAF3 in a ubiquitination cascade that activates NIK-dependent alternative NF-kappaB signaling. Nat Immunol 2008; 9: 1364-1370.

Supplementary Information accompanies the paper on Cell Death and Differentiation website (http://www.nature.com/cdd) 